Article

\title{
Probing the Energy-Environmental Kuznets Curve Hypothesis in Oil and Natural Gas Consumption Models Considering Urbanization and Financial Development in Middle East Countries
}

\author{
Haider Mahmood ${ }^{1, *}\left(\mathbb{D}\right.$, Nabil Maalel ${ }^{1,2}$ and Muhammad Shahid Hassan ${ }^{3}$ \\ 1 Department of Finance, College of Business Administration, Prince Sattam Bin Abdulaziz University, \\ 173, Alkharj 11942, Saudi Arabia \\ 2 Ecole Supérieure des Sciences Economiques et Commerciale de Tunis, University of Tunis, \\ Tunis 1089, Tunisia; n.maalel@psau.edu.sa \\ 3 Department of Economics, University of Management and Technology Pakistan, Punjab 54770, Pakistan; \\ shahid.hassan@umt.edu.pk \\ * Correspondence: h.farooqi@psau.edu.sa; Tel.: +96-6115-887-037
}

\section{check for} updates

Citation: Mahmood, H.; Maalel, N.; Hassan, M.S. Probing the

Energy-Environmental Kuznets

Curve Hypothesis in Oil and Natural

Gas Consumption Models

Considering Urbanization and

Financial Development in Middle

East Countries. Energies 2021, 14, 3178.

https://doi.org/10.3390/en14113178

Academic Editor:

Magdalena Radulescu

Received: 30 April 2021

Accepted: 21 May 2021

Published: 29 May 2021

Publisher's Note: MDPI stays neutral with regard to jurisdictional claims in published maps and institutional affiliations.

Copyright: (c) 2021 by the authors. Licensee MDPI, Basel, Switzerland. This article is an open access article distributed under the terms and conditions of the Creative Commons Attribution (CC BY) license (https:// creativecommons.org/licenses/by/ $4.0 /)$.

\begin{abstract}
Economic growth, urbanization, and financial market development (FMD) may increase energy demand in any economy. Non-renewable sources of energy consumption, i.e., oil consumption and natural gas consumption (NGC), could have environmental consequences. We examine the effects of economic growth, urbanization, and FMD on the oil consumption and NGC in Middle East countries using the period 1975-2019. In the panel results, we found a positive effect of income and a negative effect of income-squared on oil and natural gas consumption. Hence, we corroborate the existence of the environmental Kuznets curve (EKC) hypothesis in oil and natural gas consumption models of the Middle East region. Urbanization has a positive effect on oil and natural gas consumption. FMD has a positive effect on oil consumption and has a negative effect on NGC. From the long-run, country-specific results, we validate the existence of the EKC hypothesis in the oil consumption models of Iran and Iraq. The EKC is also found in the natural gas consumption models of Iran, Kuwait, and the UAE. From the short-run results, the EKC hypothesis is validated in the oil consumption models of Iran, Iraq, and Israel. The EKC is also corroborated in the NGC models of Iran, Kuwait, and the UAE. In the long run, urbanization has a positive effect on oil consumption in Iraq, Kuwait, Saudi Arabia, and Qatar. Further, urbanization has a positive effect on the NGC in Iraq, Israel, and Saudi Arabia. Conversely, urbanization has a negative effect on oil consumption in Israel. In the short run, urbanization has a positive effect on oil consumption in Iraq, Israel, Kuwait, and Qatar. Moreover, urbanization has a positive effect on the NGC in Iraq. On the other hand, urbanization has a negative effect on oil consumption in Saudi Arabia and Iran. In the long run, FMD has a positive effect on oil consumption in Saudi Arabia and Israel. In the short run, FMD has a positive effect on oil consumption in Israel, Kuwait, and Saudi Arabia. In contrast, FMD has a negative effect on oil consumption in the UAE. Moreover, a positive effect of FMD on NGC is found in the UAE. However, FMD has a negative effect on the NGC in Israel.
\end{abstract}

Keywords: oil consumption; natural gas consumption; economic growth; urbanization; financial market development

\section{Introduction}

Grossman and Krueger [1] originated the environmental Kuznets curve (EKC) hypothesis testing. The EKC explains that pollution may increase with an increase in income due to the scale effect and may decrease later because of technique and composition effects. Theoretically, the EKC has an inverted U-shaped relation in economic growth and pollution. This type of relationship has been confirmed by various studies [2-4]. However, the 
empirical literature also has corroborated the other shape of the relationship. For instance, an N-shaped curve asserts a significant increase, fall, and then increase in emissions due to increasing economic growth, while the opposite is true for reversed N-shaped curves. The N-shape EKC has been corroborated by Choi et al. [5] and Franklin and Ruth [6]. The existence of an inverted U-shaped or $\mathrm{N}$-shaped relationship corroborates the validity of the EKC hypothesis in any economy or a group of economies. On the other hand, any other shape of the relationship between pollution and economic growth does not corroborate the EKC hypothesis. The literature has also provided empirical evidence of the non-existence of the EKC. For instance, an inverted $\mathrm{N}$-form of relationship has been validated [7,8]. Alola and Donve [9] corroborated a U-shaped relationship, which explains the initial fall in pollution and later rises in pollution with increasing economic growth. Another stream of literature explored the EKC between energy variables and economic growth [10-16].

Most Middle East countries are producers of oil and gas and are also significant consumers of fossil fuel energy. Figures 1 and 2 show the per capita oil consumption and natural gas consumption (NGC). Data on oil consumption and natural gas consumption were taken from BP [17] and converted into tonnes per capita and thousands of cubic meters per capita, respectively. Figure 1 shows that the UAE and Kuwait are the largest oil consumers in most sample years. Moreover, oil consumption of all Gulf Cooperation Council (GCC) countries is found greater than other non-GCC Middle East countries, i.e., Iran, Iraq, and Israel. Salahuddin and Gow [18] mentioned that the participation of GCC economies in the oil production of the world is around twenty-five percent, and these economies preserve forty percent of their oil reserves as a percentage of the world oil reserve. Higher energy production is also associated with higher energy consumption. Hence, higher energy utilization leads to environmental harm within the region [19]. Moreover, Tolba and Saab [20] highlighted that GCC economies participate in fifty percent of carbon emissions in the Arab world. Salahuddin et al. [21] demonstrate that these economies participate around eight percent in world carbon emissions.

Figure 2 reflects that Qatar is the largest consumer of natural gas. Further, the UAE and Kuwait are standing in second and third positions in natural gas consumption in most sample years. Hence, we may consider that both oil consumption and natural gas consumption are closely linked with production. Hence, the Middle East countries' oil and natural consumption would have environmental consequences and need attention to investigate their determinants. For instance, Callen et al. [22] claimed that earnings from oiland gas-related products are generally utilized to finance economic activities in the GCC region. The main objective of these sorts of activities is to accelerate the economic growth of the economy, which may also accelerate the energy demand. The prime reliance of Middle East countries is on fossil fuel energy consumption, which may have environmental consequences. On the other hand, after some threshold point, economic growth may also switch to renewables and reduce the fossil fuel energy demand. Therefore, it is very pertinent to test the energy-EKC of fossil fuels in the Middle East countries.

The literature has examined the EKC in the relationship between income and pollution in the Middle East and North African (MENA) region using the period 1981-2013 [23] and using the period 1990-2011 [19]. However, the testing of the energy-EKC hypothesis in the relationship between energy variables and income is scant in the global literature [10-16] and absent in the Middle East literature. Figures 1 and 2 shows that the Middle East countries are majorly dependent on oil and natural gas consumption, which may have environmental consequences. Therefore, it seems pertinent to empirically explore the quadratic effect of economic growth on oil and natural gas consumption. This empirical exercise would confirm a positive monotonic effect, a negative monotonic effect, or a quadratic effect of economic growth on oil and natural gas consumption. Hence, it will help us to understand the environmental consequences of economic growth in Middle East countries. In the empirical testing of the energy-EKC hypothesis, the existing literature has ignored urbanization $[11,12,14]$, which may play an essential role in accelerating the energy demand and shaping the energy-EKC $[13,15,16]$. Moreover, the role of financial 
market development (FMD) is ignored in testing the energy-EKC hypothesis. In addition, Li et al. [16] realized the importance of analyses of disaggregated energy demand in testing the energy-EKC hypothesis, which has been ignored in the energy-EKC literature [10-15]. Hence, this present study is aimed to explore the energy-EKC hypothesis in the Middle East region using the period 1975-2019, considering two major sources of energy demand in this region, i.e., oil and natural gas consumption, and considering the roles of urbanization and FMD in shaping the energy-EKC. In this state-of-the-art report, we contribute to the empirical literature in four ways. First, energy-EKC hypothesis testing is scant in the global literature and absent in the Middle East region. Second, the EKC is tested in the MENA region using the period 1981-2013 and 1990-2011 [19,23], and we utilize the maximum available range of sample years from 1975 to 2019. Third, testing the role of FMD in shaping the energy-EKC is absent in the global and Middle East literature. Fourth, the testing of disaggregated energy demand is scant in the energy-EKC hypothesis literature.

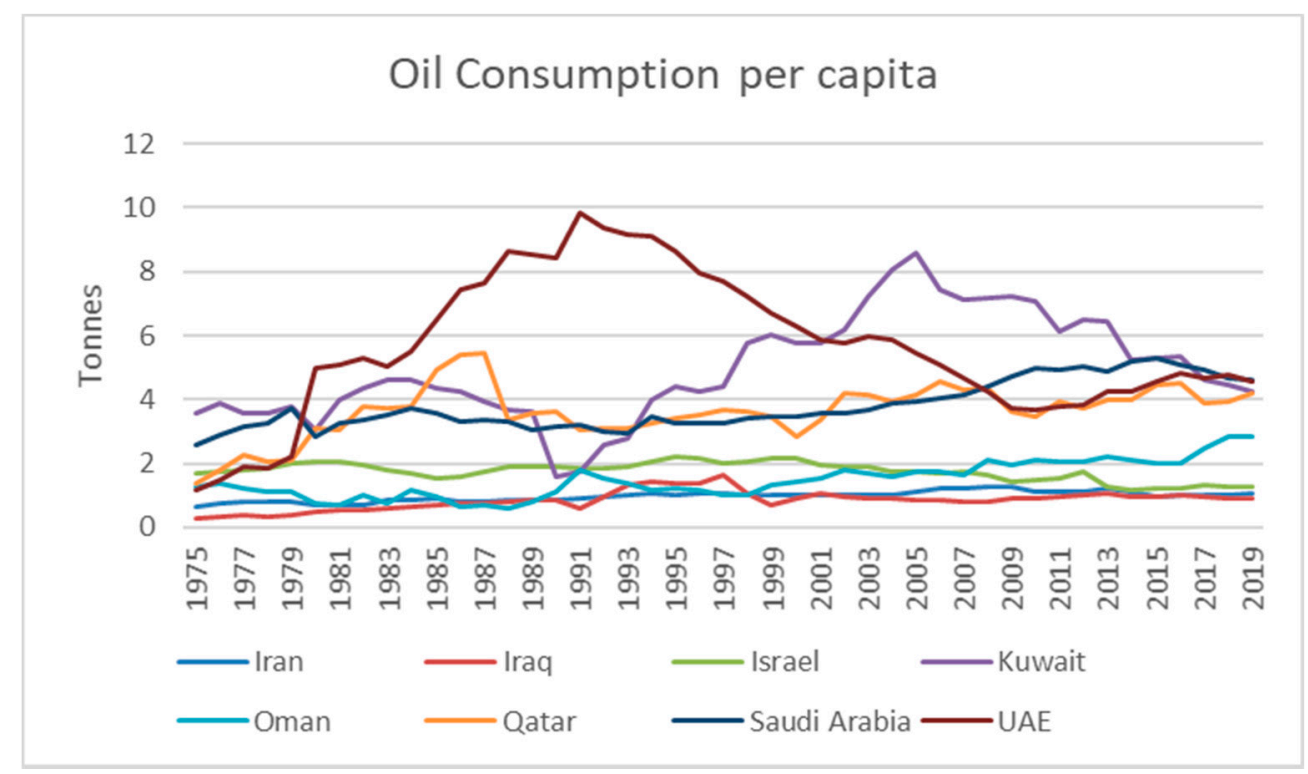

Figure 1. Oil consumption per capita.

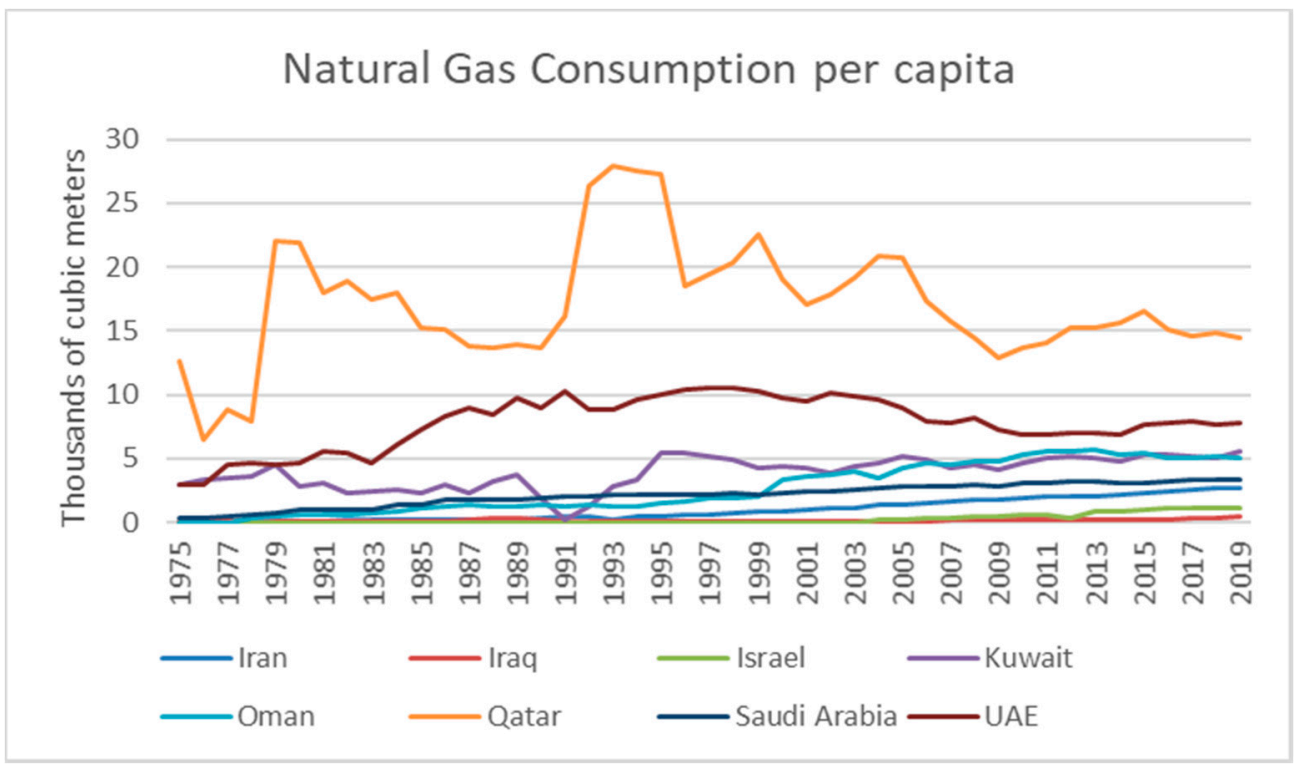

Figure 2. Natural gas consumption. 


\section{Literature Review on the EKC Hypothesis}

\subsection{Quadratic EKC}

Some studies tested the EKC in large panels. For instance, Hassan et al. [24] studied the nonlinear effects of disaggregated Gross Domestic Product (GDP) in agriculture, industry, and service value-added on pollutant emissions in 189 countries worldwide. After employing Quantile Regression from 1990 to 2018, the results demonstrated the EKC, with an association between the service sector value-added and emissions. The results further exposed evidence of the U-curved connection between industrial value-added and emissions. At the same time, a linear interrelation was evident in the effect of agriculture value-added on emissions, and the EKC was not evident in the case of industrial and agricultural GDP. Chen et al. [25] examined the presence of EKC in 188 countries worldwide. After employing the panel Autoregressive Distributive Lag (ARDL) technique on the data series from 1993 to 2010, this study provided the absence of the EKC hypothesis in the relationship between GDP and emissions. However, the study also found bidirectional causal interrelations between energy and growth.

Maneejuk et al. [26] explored the EKC between GDP and emissions in 8 selected groups of 44 countries. Using panel kink regression and a data series from 2001 to 2016, the results disclosed an absence of the EKC in 5 out of 8 countries' groups, and the EKC was corroborated in the rest of the countries' groups. Jin and Kim [27] explored a panel of 34 countries to test the authenticity of an asymmetric impact of GDP on pollution. After applying panel estimators, the study confirmed evidence of EKC in the association between both variables. In the country-specific results, the evidence of EKC was witnessed in the United Kingdom, Turkey, Austria, France, and Australia. In the rest of the countries, the study did not confirm the evidence of the EKC. In another study, Hassan et al. [28] tested the nonlinear impact of GDP on emissions in 32 developed and 32 developing economies. After using the panel model on the data series from 1970 to 2015, the study provided evidence of the EKC between GDP and emission in developed economies. Moreover, the long-run EKC was witnessed for developing economies. Bongers [29] corroborated the EKC hypothesis between GDP and emissions with a condition of high substitutability between the fossil and renewable energy mix in any country.

Bibi and Jamil [30] investigated the EKC between GDP and pollutant emissions in six regions. After employing a fixed effect estimator on the sample of 2000 to 2018, this study provided evidence of EKC between emissions and growth in five out of six regions. The EKC was not witnessed in Africa. Sulaiman and Rahim [3] tested the EKC hypothesis for some African economies, such as Mauritius, Egypt, Kenya, Algeria, Morocco, South Africa, Zambia, and Tunisia. In the EKC testing, the authors incorporated technology, biomass, and fossil fuel as control variables. Using data from 1980 to 2015, they found results in favour of the EKC hypothesis. Moreover, biomass was reducing emissions, while fossil fuels were accelerating emissions. In a dynamic analysis, Shahzad et al. [31] investigated 29 developed countries from 1994 to 2018. The authors corroborated the positive effects of urbanization, GDP, and environmental policy on renewable electricity generation.

Wang et al. [32] tested the EKC in five Central Asian economies, namely, Kazakhstan, Kyrgyzstan, Uzbekistan, Tajikistan, and Turkmenistan. The study considered the IPAT framework on the sample from 1992 to 2014 and found the EKC in Uzbekistan. A U-shaped relation was witnessed in Tajikistan. Hence, the EKC was not found in Tajikistan and the rest of the three countries. Saboori and Sulaiman [33] scrutinized the asymmetric effect of GDP on pollution in some Asian economies. After using the ARDL bounds testing method on a data series from 1971 to 2009, the results provided the presence of the EKC between GDP and emissions in Thailand and Singapore, while the reverse case was found in Indonesia and the Philippines. Xue et al. [34] scrutinized the influence of renewable and non-renewable energy and GDP on ecological footprints in four South Asia countries using data from 1990 to 2016. The study provided evidence of EKC in the panel. In the countryspecific results, the EKC was proved in Sri Lanka. The results further provided evidence of U-curved interconnection between both variables in Pakistan and India. Lastly, the study 
disclosed that renewable energy utilization significantly curtailed ecological footprints. On the other hand, non-renewables significantly accelerated ecological footprints in the panel and country-specific results.

Pao and Tsai [35] took a sample of Brazil, Russia, India, and China (BRIC) for testing the nonlinear impact of GDP on emissions. The study considered the panel and also tested the country-specific results as well. The study took a sample of 1971 to 2005 for Brazil, India, and China, while for Russia, the sample was taken from 1990 to 2005. The empirical long-run results provided evidence of an EKC between GDP and emissions in India and China in the country-specific results. In the panel's result, the EKC was also found valid. In the case of Russia, the U-curved relation was evident. In another study, including South Africa, Akadiri et al. [4] reconnoitred the nonlinear impact of GDP and economic freedom on emissions in BRICS economies. After applying the pooled mean group method on a sample from 1995 to 2018, the study found the EKC in the long run, while the reverse case was evident in the short run in five countries. Moreover, the conclusion remained the same after excluding economic freedom from the analysis. On the other hand, no evidence of the EKC was found in the country-specific results.

Rufael and Weldemeskel [36] investigated the nonlinear effect of environmental stringency on emissions in Turkey, Indonesia, Brazil, India, Russia, South Africa, and China. The study used the panel ARDL technique on a sample from 1993 to 2014 and found a quadratic impact of stringency policy. Hence, the EKC was corroborated in the panel and was not found in the country-specific results. Miranda et al. [37] examined the EKC in Canada, Mexico, and the USA. The authors found the relevance of EKC in Mexico and the USA, but the EKC was not corroborated in Canada. Rahman et al. [2] examined the nonlinear effect of GDP on $\mathrm{CO}_{2}$ emissions in four countries, such as Myanmar, India, Bangladesh, and China, from 1972 to 2014, and corroborated the EKC in the panel. The study also found country-specific results by using the bounds testing approach by considering breaks. The country-wise results confirmed EKC in Bangladesh, India, and China. Nevertheless, no witness of the EKC was found in Myanmar.

The literature has also probed a single country EKC. For instance, Mahmood et al. [38] scrutinized the nonlinear effect of GDP on emissions in Tunisia. The study applied linear and nonlinear ARDL bounds testing approaches on the data series from 1971 to 2014. It exposed the validity of EKC in Tunisia. Hashmi et al. [39] investigated the EKC in Pakistan, controlling the service sector in the model. The authors corroborated the EKC in the presence of the service sector in the model. Moreover, a bidirectional causality was found between the service sector and emissions. Employing the ARDL on a sample from 1965 to 2017, Alola and Donve [9] found a U-shaped association between GDP and emissions in Turkey. Hence, the findings did not support an EKC in Turkey. Mahmood et al. [40] examined the nonlinear influence of GDP and agriculture value-added as a share of GDP on emissions in Saudi Arabia to test for an EKC. After employing the ARDL model from 1971 to 2014, the authors supported the EKC hypothesis between GDP and emissions, while the presence of EKC in the form of agriculture share and emissions was also evident in Saudi Arabia.

In the context of the Middle East region, Zaied et al. [23] took the MENA region to test the EKC. The empirical results of the dynamic regression for the sample from 1980 to 2012 demonstrated confirmation of the EKC between carbon dioxide emissions and GDP in the MENA region. Alsamara et al. [41] investigated the EKC between GDP and emissions in the GCC region. The study used panel methods on the data series from 1980 to 2017 and found an EKC between GDP and sulphur emissions in the overall sample. The country-level results disclosed the EKC between GDP and emissions in all GCC countries except Oman. In Oman, a U-shaped relation was seen between emissions and GDP. Ansari et al. [42] aimed at testing the nonlinear impact of GDP on pollution in GCC from 1991 to 2017 and the EKC was not verified. Mahmood et al. [43] considered an asymmetric role of GDP on $\mathrm{CO}_{2}$ emissions in Saudi Arabia. The study used nonlinear ARDL for the sample from 1971 
to 2014 and found the EKC in the long run in Saudi Arabia. Moreover, decreasing FMD showed a negative environmental impact in terms of increasing emissions.

\subsection{Cubic EKC}

The cubic equations were inspected by Ozokcu and Ozdemir [44] to test EKC. They applied panel regressions on the data series from 1980 to 2010 and found an inverted Nshaped relation between income and emission in 26 Organization for Economic Cooperation and Development (OECD) economies. The results further reported an N-shaped relation between income and emissions in 52 emerging economies. Kilic and Balan [45] investigated the association between emissions and income for 151 countries worldwide. After using a data series from 1996 to 2010, the study concluded a cubic polynomial EKC in the panel of 151 countries. Zarzoso and Motrancho [46] inspected an asymmetric connection between GDP and emission in 22 OECD countries. The study applied the pooled mean group estimator on the sample from 1975 to 1998 and found an N-shaped connection between GDP and emissions. Lee et al. [47] tested the asymmetric effect of GDP on $\mathrm{CO}_{2}$ emissions in 89 countries. They applied various panel methods on the data series from 1960 to 2000. They found an N-shaped association between GDP and emissions in all the selected countries. The empirical results of the dynamic panel method reported an $\mathrm{N}$-shaped relation in high- and low-income countries while an inverted $\mathrm{N}$-shaped relation was witnessed in middle-income countries.

Choi et al. [5] examined the cubic impact of GDP on pollution in three countries, namely, China, Korea, and Japan. The study applied multiple regression models on the data from 1971 to 2006 and found evidence of N-shaped interconnection between GDP and pollution in China and an inverted N-shaped relation between GDP and pollution in both Korea and Japan. Menz and Kuhling [7] attempted to investigate the N-shaped relation between income and sulphur dioxide in 25 OECD countries. After utilizing the panel fixed effect procedure from 1970 to 2000, the results asserted an inverted $\mathrm{N}$-shaped relation between income and sulphur dioxide in the selected 25 OECD countries. Franklin and Ruth [6] conducted their study to estimate the N-shaped association between GDP and emissions in the USA using a sample from 1800 to 2000. The results supported the $\mathrm{N}$-shaped association between both actors of the study. The estimates provided evidence of an EKC between both actors for the period from 1900 to 2000. Chang et al. [8] reconnoitred the nonlinear effect of GDP on the carbon footprints in 98 countries from developed, developing, and underdeveloped world. After employing Panel techniques on the data series from 1999 to 2007, the authors found an inverted N-shaped relation between carbon footprint and GDP in the 98 countries, which confirmed the absence of an EKC in these countries. Simionescu et al. [48] investigated the EKC in Central and Eastern Europe from 1996 to 2019 and corroborated the N-shaped relationship between GDP and emissions.

\subsection{Energy-EKC}

Suri and Chapman [10] were among the pioneer to test the nonlinear effects of GDP on energy use in 33 countries worldwide. This study used the data period from 1971 to 1991 and found the EKC between GDP and energy use in the selected countries during the selected sample period. Luzzati and Orsini [11] scrutinized the energy-EKC between GDP and energy variable in 113 countries. After employing parametric and nonparametric estimators for the sample from 1971 to 2001, the study did not provide evidence of an EKC in the selected countries. Pablo-Romero and De Jesus [12] explored the energy-EKC using panel data technique on a sample from 1990 to 2011. The authors did not find the EKC between income and energy use in the 22 Caribbean and Latin American economies. Aboagye [13] probed the nonlinear effect of growth on energy usage and energy intensity in Ghana. The study considered the ARDL model approach on the data series from 1981 to 2014 and found the EKC in the long run. The study further found a feedback hypothesis in growth and energy. Moreover, bidirectional causality was also witnessed between the 
growth-squared term and energy intensity. The growth-squared term was causing energy utilization, but the reverse was not evident in Ghana.

Aruga [14] attempted to scrutinize the EKC between energy usage and economic growth in 19 Asia-Pacific economies. After using various panel techniques on the sample period from 1990 to 2014, this study found EKC in high-income countries. However, the EKC was not found in the whole panel. Hundie and Daksa [15] studied the effect of growth on energy utilization as a share of GDP for the Ethiopian economy from 1974 to 2014. They concluded the EKC hypothesis in Ethiopia. However, the causality test results did not provide any evidence of a causal link between growth and energy. Li et al. [16] tested the cubic effect of growth on energy sources, i.e., oil, coal, and gas consumption in 21 regions of China. After using the sample from 2000 to 2017, the study provided evidence of an inverted $\mathrm{N}$-shaped relation between growth and energy sources.

This literature review has disclosed the vast literature on testing the EKC hypothesis concerning the pollutant emission and economic growth nexus. However, the testing of the energy-EKC is scant in the global literature and missing in the case of Middle East countries. Hence, this present study fills this gap by testing the EKC hypothesis with two energy sources, i.e., oil consumption and natural gas consumption.

\section{Methods}

\subsection{Data and Model}

Our main objective is to test the EKC hypothesis in the relationship between energy consumption variables and economic growth in the Middle East countries. We test the quadratic effect of GDP per capita on oil and natural gas consumption, major sources of energy consumption in most Middle East countries. Moreover, we include some control variables, which may accelerate the energy demand. For instance, urbanization boosts energy consumption because of the demand for multiple electrical appliances and automobiles due to urbanization. Besides, the increasing FMD is also financing the business and consumption activities, requiring extensive energy to run. Hence, both urbanization and financial development may increase energy consumption. Therefore, we hypothesize the following models to test the energy-EKC hypothesis:

$$
\begin{aligned}
\mathrm{LOC}_{i t} & =\mathrm{f}\left(\mathrm{LGDPC}_{\mathrm{it}}, \mathrm{LGDPC}_{\mathrm{it}}{ }^{2}, \mathrm{LURB}_{i t}, \mathrm{LFMD}_{\mathrm{it}}\right) \\
\mathrm{LNGC}_{\text {it }} & =\mathrm{f}\left(\mathrm{LGDPC}_{\mathrm{it}}, \mathrm{LGDPC}_{\mathrm{it}}{ }^{2}, \mathrm{LURB}_{\mathrm{it}}, \mathrm{LFMD}_{\mathrm{it}}\right)
\end{aligned}
$$

$\mathrm{LOC}_{\mathrm{it}}$ is the natural logarithm of oil consumption in tonnes per capita. LNGC $\mathrm{it}_{\mathrm{it}}$ the natural logarithm of natural gas consumption in thousands of cubic meters per capita. Oil and natural gas consumption data were taken in a million tonnes and billion cubic meters from BP [17]. Then, oil and natural gas consumption were converted into tonnes per capita, and thousands of cubic meters per capita, respectively, using some mathematic identities and then converted into per capita by dividing the population of the respective countries. LGDPC $_{i t}$ is the natural logarithm of GDP per capita. LURB it is the natural logarithm of a percentage of the urban population of the total population. $\mathrm{LFMD}_{\text {it }}$ is a natural logarithm of domestic credit to the private sector by banks as a percentage of GDP, a proxy for financial development. $t$ shows a period of 1975-2019, and i represents eight Middle East countries, namely, Iran, Iraq, Israel, Kuwait, Oman, Qatar, Saudi Arabia, and the UAE. The rest of the Middle East countries are ignored due to the unavailability of data for the sample period. Data on population, urbanization, and FMD were sourced from the World Bank [49].

\subsection{Panel Cointegration}

We first tested for the EKC in a panel of eight Middle East countries. For this purpose, we used different cointegration tests to verify the long-run relationships in the hypothesized models. Before applying cointegration in the panel models, it is pertinent to check the unit root problem in the panel series. To test the unit root, we applied the Im-Pesaran-Shin 
(IPS) test of Im et al. [50], Levin-Lin-Shin (LLS) test of Levin et al. [51], and FisherAugmented Dickey Fuller (ADF) test of Maddala and Wu [52]. Then, we applied the Kao [53] cointegration test with the following equation:

$$
y=\beta^{\prime} X+e
$$

where $y$ is a vector of the dependent variables, and $X$ is a vector of the explanatory factors mentioned in Equations (1) and (2). After regressing Equation (3) by Ordinary Least Square (OLS), we applied the ADF test on the residual $e$. If residual is stationary at a level, then we may claim for cointegration in Equation (3). Then, we applied Maddala and $\mathrm{Wu}$ [52] cointegration test in the following way:

$$
y=-2 \sum_{i=1}^{N} \log _{e}\left(\pi_{i}\right)
$$

Equation (4) was utilized to find the cumulative probability of a panel of the Middle East countries from the individual Trace and Maximum Eigenvalues of Johansen [54]. Moreover, we applied Pedroni [55] to verify the cointegration in a panel of the Middle East countries. Using regression Equation (3), Pedroni [55] suggested the following seven test statistics to verify cointegration:

Within dimensions:

$$
\begin{gathered}
T^{2} N \sqrt{N} Z_{\hat{v} N, T}=T^{2} N \sqrt{N} /\left(\sum_{i=1}^{N} \sum_{t=1}^{T} 1 / \hat{L}_{11 i}^{2} \hat{e}_{i, t-1}^{2}\right) \\
T \sqrt{N} Z_{\hat{\rho} N, T-1}=T^{2} \sqrt{N}\left(\sum_{i=1}^{N} \sum_{t=1}^{T} 1 / \hat{L}_{11 i}^{2} \hat{e}_{i, t-1} \Delta \hat{e}_{i, t}-\hat{\lambda}_{i}\right) /\left(\sum_{i=1}^{N} \sum_{t=1}^{T} 1 / \hat{L}_{11 i}^{2} \hat{e}_{i, t-1}^{2}\right) \\
Z_{t N, T}=\left(\sum_{i=1}^{N} \sum_{t=1}^{T} 1 / \hat{L}_{11 i}^{2} \hat{e}_{i, t-1} \Delta \hat{e}_{i, t}-\hat{\lambda}_{i}\right) / \sqrt{\left(\widetilde{\sigma}_{N, T}^{2} \sum_{i=1}^{N} \sum_{t=1}^{T} \hat{L}_{11 i}^{-2} \hat{e}_{i, t-1}^{2}\right)} \\
Z_{t N, T}^{*}=\left(\sum_{i=1}^{N} \sum_{t=1}^{T} 1 / \hat{L}_{11 i}^{2} \hat{e}_{i, t-1}^{*} \Delta \hat{e}_{i, t}^{*}\right) / \sqrt{\left(\widetilde{s}_{N, T}^{* 2} \sum_{i=1}^{N} \sum_{t=1}^{T} 1 / \hat{L}_{11}^{2} \hat{i}_{i, t-1}^{* 2}\right)}
\end{gathered}
$$

Between dimensions:

$$
\begin{gathered}
T \sqrt{N} \widetilde{Z}_{\hat{\rho} N, T-1}=T .1 / \sqrt{N}\left(\sum_{t=1}^{T} \hat{e}_{i, t-1} \Delta \hat{e}_{i, t}-\hat{\lambda}_{i}\right) \sum_{i=1}^{N}\left[\frac{1}{\sum_{t=1}^{T} \hat{e}_{i, t-1}^{2}}\right] \\
1 / \sqrt{N} \widetilde{Z}_{t N, T}=\frac{1}{\sqrt{N}\left(\sum_{t=1}^{T} \hat{e}_{i, t-1} \Delta \hat{e}_{i, t}-\hat{\lambda}_{i}\right)} \cdot 1 /\left[\sum_{i=1}^{N}\left(\hat{\sigma}_{i}^{2} \sum_{t=1}^{T} \hat{e}_{i, t-1}^{2}\right)\right] \\
1 / \sqrt{N} \widetilde{Z}_{t N, T}^{*}=\frac{1}{\sqrt{N}\left(\sum_{t=1}^{T} \hat{e}_{i, t-1}^{*} \Delta \hat{e}_{i, t}^{*}\right)} \cdot 1 / \sqrt{\sum_{i=1}^{N}\left(\sum_{t=1}^{T} \hat{s}_{i}^{* 2} \hat{e}_{i, t-1}^{* 2}\right)}
\end{gathered}
$$

The above statistics in Equations (5)-(11) consider the heterogeneity in the individual cross-sections [54]. After confirming the cointegration from the above three tests, we verified the cointegration by applying the Westerlund [56] approach. This methodology removes the restriction on the common factor and follows Banerjee et al. [57]. The suggested four statistics are as follows:

$$
G_{T}=\frac{1}{N} \sum_{i=1}^{N}\left(\frac{\hat{\alpha}_{i}}{\text { Standard Error }\left(\hat{\alpha}_{i}\right)}\right)
$$




$$
\begin{gathered}
G_{\alpha}=\frac{1}{N} \sum_{i=1}^{N}\left(\frac{T \hat{\alpha}_{i}}{\hat{\alpha}_{i}(1)}\right) \\
P_{T}=\frac{\hat{\alpha}}{\text { Standard Error }(\hat{\alpha})} \\
P_{\alpha}=T \hat{\alpha}
\end{gathered}
$$

In Equations (12)-(15), $\hat{\alpha}_{i}$ is the error correction coefficient. All of the above cointegration techniques are worked on $\mathrm{H}_{0}$ : no cointegration. If the absolute values of the estimated statistics are found to be more than the critical value or the $p$-values are found to be less than 0.1 , then we reject $\mathrm{H}_{0}$ and claim cointegration in the panel model.

After confirming the cointegration in the models, the Pooled Mean Group (PMG) estimators of Pesaran et al. [58] were utilized to capture the panel's long- and short-run effects, hypothesized as independent variables in the energy consumption variables. The PMG estimators are ARDL in nature and regard the model's possible endogeneity. The general form of PMG is as follows:

$$
\begin{gathered}
\Delta y_{i t}=\alpha_{i}+\sum_{j=1}^{p-1} \gamma_{j} \Delta y_{i, t-1}+\sum_{j=0}^{q-1} \beta_{j} \Delta x_{i, t-1}+\mu_{1} y_{i, t-1}+\mu_{2} x_{i, t-1}+\Omega_{1 i t} \\
\Delta y_{i t}=\alpha_{i}+\sum_{j=1}^{p-1} \gamma_{j} \Delta y_{i, t-1}+\sum_{j=0}^{q-1} \beta_{j} \Delta x_{i, t-1}+\varphi_{j} e_{i, t-1}+\Omega_{2 i t}
\end{gathered}
$$

$\mu_{2}$ can be normalized in Equation (16) to find the long-run effects of the model. $\gamma_{i}$ and $\beta_{i}$ are the short-run effects in Equation (17). $\varphi_{j}$ is an error correction term $\left(\mathrm{ECT}_{\mathrm{t}-1}\right)$ in Equation (17), and cointegration may be claimed with an estimated negative value. Moreover, it also represents the speed of adjustment. After applying PMG, the Fully Modified OLS (FMOLS) was employed to confirm the conclusions from the PMG estimators. We discussed the FMOLS of Pedroni [59], which correct endogeneity problems and serial correlation in the model. The FMOLS estimators may calculate as follows:

$$
\hat{\beta}_{F M O L S}=\left(\sum_{n=1}^{N}\left(\sum_{t=1}^{T}\left(x_{i t}-\bar{x}_{i}\right) \hat{y}_{i t}^{+}+T \hat{\Delta}_{\varepsilon \mu}^{+}\right)\right) /\left(\sum_{i=1}^{N} \sum_{t=1}^{T}\left(x_{i t}-\bar{x}_{i}\right)^{\prime}\right)
$$

$\hat{\Delta}_{\varepsilon \mu}^{+}$corrects the serial correlation and $y_{\varepsilon \mu}^{+}$corrects the endogeneity. Besides, we also applied the Dynamic OLS (DOLS) of Kao and Chiang [60], which include both the lead-and lag-differenced variables in the following form:

$$
Y_{i t}=a_{i}+X_{i t}^{\prime} b+\sum_{k=-p_{1}}^{k=+p_{2}} c_{i k} \Delta x_{i, t+k}+v_{i t}
$$

$c_{i j}$ are parameters to capture the lag and lead effects of the differenced independent variables. Moreover, the DLOS parameters can be estimated as follow:

$$
\hat{b}_{D O L S}=\left(\sum_{t=1}^{T} z_{i t} \hat{z}_{i t}^{+}\right) \cdot \sum_{i=t}^{N} 1 / \sum_{t=1}^{T} z_{i t} z_{i t}^{\prime}
$$

\subsection{Time Series Cointegration}

After performing the panel cointegration, our objective was to test the individual country's time series results to check the EKC in each Middle East countries. For this purpose, we tested the unit root in each variable using $\mathrm{Ng}$ and Perron [61]. Then, we applied the ARDL cointegration of Pesaran et al. [62]. Due to the autoregressive process, 
this technique provides efficient results in the mixed order of integration and regard endogeneity in the model. The ARDL and its Error Correction Model (ECM) are as follows:

$$
\begin{gathered}
\Delta y_{t}=\alpha+\sum_{k=1}^{m-1} \gamma_{j} \Delta y_{t-1}+\sum_{l=0}^{n-1} \beta_{j} \Delta x_{t-1}+c y_{t-1}+d x_{t-1}+e_{t} \\
\Delta y_{i t}=\alpha_{i} \sum_{k=1}^{m-1} \gamma_{j} \Delta y_{t-1}+\sum_{l=0}^{n-1} \beta_{j} \Delta x_{t-1}+g E C T_{t-1}+t
\end{gathered}
$$

The cointegration can be tested on $\mathrm{H}_{0}$ : no-cointegration $(c=d=0)$. The rejection of $\mathrm{H}_{0}$ would validate cointegration. Furthermore, the long-run effects were calculated, normalizing the coefficients $\left(\beta_{j}\right)$, normalized by $\left(\gamma_{j}\right)$. Moreover, the Error Correction Term $\left(\mathrm{ECT}_{\mathrm{t}-1}\right)$ was replaced by $c_{1} y_{t-1}+d_{2} x_{t-1}$ to form the ECM in Equation (22). The coefficient of $\mathrm{ECT}_{\mathrm{t}-1}$ shows the short-run relationships and a speed of adjustment in the model. Moreover, its negative coefficient also alternatively confirms the model's cointegration [62].

\section{Data Analyses and Discussion}

In Appendix A, Table A1 displays the IPS, LLC, and Fisher-ADF panel unit root tests to verify the stationarity of the panel series of our hypothesized variables of oil and natural gas consumption models. Results of all the unit root tests corroborate the unit root problem in all the panel series at the level. However, the series is stationary at first at a $1 \%$ level of significance in all the applied tests, except the LLC test in the case of $\triangle \mathrm{LURB}_{\text {it }}$ with the intercept and trend. The LLC test shows stationarity of $\triangle \mathrm{LURB}_{\text {it }}$ at a $5 \%$ level of significance with the intercept and trend in the analysis. Hence, the order of integration is one for both the oil and natural gas consumption models.

In Appendix A, Table A2 shows four panel cointegration tests for a model with oil consumption as the dependent variable, mentioned in Equation (1) in the methodology section. Pedroni test corroborates cointegration in the model with four out of seven test statistics. Further, the error term is stationary in the Kao test. Hence, the Kao test corroborates the cointegration. Similarly, the Fisher-Johansen test shows the five cointegrating vectors in the trace statistics and four cointegrating vectors in maximum eigen statistics. It provides sufficient evidence of cointegration in the model. Lastly, the Westerlund test corroborates the significant long-run relationship with $G_{t}$ statistics at a $1 \%$ level of significance. All four cointegration tests corroborated cointegration in the oil consumption model. Hence, we can proceed with further analyses.

In Appendix A, Table A3 shows four panel cointegration tests for a model with the dependent variable natural gas consumption, mentioned in Equation (2) in the methodology section. Pedroni test corroborates cointegration in the model with six out of seven test statistics. Kao test shows that the error term is stationary at a $1 \%$ level of significance. Hence, the Kao test corroborates the cointegration. Moreover, the Fisher-Johansen test shows the five cointegrating vectors in both the trace and maximum eigen statistics. Hence, this test also provides sufficient evidence of cointegration in the model. Lastly, the Westerlund test corroborates the cointegration in $\mathrm{Gt}, \mathrm{Pt}$, and Pa statistics. All four cointegration tests corroborated cointegration in the natural gas consumption (NGC) model. Hence, we can proceed with further analysis.

In Appendix A, Table A4 shows the FMOLS, DOLS, and PMG results of both the oil consumption and NGC models. In all estimations, the coefficients of LGDPC $_{i t}$ and LGDPC $_{\text {it }}{ }^{2}$ are positive and negative, respectively, in both the oil consumption and NGC models. Hence, the EKC is corroborated in both oil consumption and NGC cases in the Middle East countries. Urbanization has a positive effect on both oil consumption and NGC in all estimates. Hence, increasing urbanization promotes oil consumption and NGC in the economy; this is natural, as increasing urbanization requires energy to fuel urban activities. Increasing urbanization requires both consumption and production-based energy requirement. Therefore, increasing urbanization is increasing both oil consumption and 
NGC. FMD has a positive effect on oil consumption in the FMOLS and DOLS estimates but has an insignificant impact in PMG results. The increasing FMD may provide more loans for both production and consumption activities. Hence, the oil demand may rise in the oil-rich Middle East countries. On the other hand, FMD negatively affects the natural gas consumption in FMOLS estimates and has a statistically insignificant effect in the DOLS and PMG estimates. The negative effect of FMD on natural gas consumption realizes two issues. At first, it may be possible that increasing FMD is promoting energy-efficient technologies and is helping to reduce natural gas consumption. On the other hand, increasing FMD may also shift the energy demand from natural gas consumption to oil consumption or other renewable and non-renewable energy sources. This fact is also corroborated with a positive effect of FMD on oil consumption.

After the panel analyses, we also conducted a time-series analysis of each individual country's case, to observe the effects of the hypothesized variables on energy consumption. In Appendix A, Table A5 shows the Ng-Perron test. The results show that all variables in all countries' cases are nonstationary at that level, but that there are some stationary cases, i.e., $\mathrm{LFMD}_{\mathrm{t}}$ with intercept and trend in Iraq, the UAE, and Oman; $\mathrm{LGDPC}_{\mathrm{t}}$ with intercept and trend in Israel; and $\mathrm{LURB}_{\mathrm{t}}$ with intercept in the UAE. At first difference, all variables of all countries are stationary, except $\mathrm{LURB}_{\mathrm{t}}$ in $\mathrm{Oman}$. Hence, the evidence of a mixed order of integration is found in the models of Iraq, Oman, Israel, and the UAE. The order of integration is one for the rest of the countries' models. In both cases of integration, we may move for cointegration as ARDL is efficient in such circumstances. However, we cannot perform ARDL cointegration in Oman as the urbanization is not nonstationary at both level and first difference. However, we performed the analysis in Oman for completeness.

In Appendix A, Table A6 shows the results of the bound testing. We use the critical values of Kripfganz and Schneider [63], which are efficient in a small sample. In the LOC $_{t}$ model, cointegration is corroborated in Iraq and the UAE at 1\%, in Israel and Qatar at $5 \%$, and in KSA and Kuwait at the $10 \%$ level of significance. However, the bound test could not validate cointegration in Iran and Oman. Tables 1 and 2 show the long run results. Moreover, Tables 3 and 4 shows the short run results. Cointegration in the LOC $_{t}$ models of Iran and Oman is validated alternatively with negative coefficients of $\mathrm{ECT}_{\mathrm{t}-1}$ in Table 3. In the $\mathrm{LNGC}_{\mathrm{t}}$ model, cointegration is verified in Israel, Kuwait, Saudi Arabia, and the UAE at 1\%, in Oman at 5\%, and in Iraq and Iran at the 10\% level of significance. However, cointegration is not validated through the bound test in Qatar, which is validated alternatively with negative coefficients of $\mathrm{ECT}_{\mathrm{t}-1}$ in Table 4. Lastly, the diagnostic tests corroborate that the estimated models have no econometric issues.

Table 1 shows the long-run results of the $\mathrm{LOC}_{t}$ model. The EKC is verified with positive and negative parameters of $\mathrm{LGDPC}_{t}$ and $\mathrm{LGDPC}_{t}{ }^{2}$ in Iran and Iraq. However, an inverse situation is found in the case of the UAE, with negative and positive parameters of LGDPC $\mathrm{t}_{t}$ and LGDPC ${ }_{t}{ }^{2}$. In Israel, the coefficients of LGDPC $t$ and LGDPC ${ }_{t}{ }^{2}$ were found to be positive and statistically insignificant, respectively. Hence, a linear positive effect of economic growth is found on oil consumption in Israel. Further, the effect of growth on oil consumption is corroborated, being statistically insignificant in Kuwait, Oman, Qatar, and Saudi Arabia. Urbanization has a positive effect on the oil consumption in Iraq, Kuwait, Saudi Arabia, and Qatar. Hence, increasing urbanization accelerates the oil demand in Iraq, Kuwait, Saudi Arabia, and Qatar. Urbanization negatively affects oil consumption in Israel. Hence, increasing urbanization helped Israel in decreasing oil consumption. It may be due to switching energy demands towards renewable energy sources and adopting energyefficient technology in Israel. Moreover, urbanization could not affect the oil consumption in Iran, Oman, and the UAE. FMD positively affects the oil consumption in Israel and Saudi Arabia. Hence, increasing financial development is increasing the oil consumption in Israel and Saudi Arabia. Further, FMD could not affect the oil consumption in Iran, Iraq, Kuwait, Oman, Qatar, and the UAE. 
Table 1. Long-run results: $\mathrm{LOC}_{t}$ as the dependent variable.

\begin{tabular}{|c|c|c|c|c|c|}
\hline Country & Variable & Coefficient & Std. Error & $t$-Statistic & Prob. \\
\hline \multirow[t]{5}{*}{ Iran } & LGDPC $_{t}$ & 0.6604 & 0.2924 & 2.2584 & 0.0297 \\
\hline & $\mathrm{LGDPC}_{\mathrm{t}}{ }^{2}$ & -0.0159 & 0.0085 & -1.8601 & 0.0706 \\
\hline & LURB $_{\mathrm{t}}$ & -1.9851 & 1.2665 & -1.5674 & 0.1253 \\
\hline & LFMD $_{\mathrm{t}}$ & -0.0689 & 0.1363 & -0.5058 & 0.6159 \\
\hline & Intercept & 2.0802 & 3.6875 & 0.5641 & 0.5760 \\
\hline \multirow[t]{5}{*}{ Iraq } & LGDPC $_{t}$ & 0.6518 & 0.1640 & 3.9744 & 0.0003 \\
\hline & $\mathrm{LGDPC}_{\mathrm{t}}{ }^{2}$ & -0.0277 & 0.0073 & -3.7929 & 0.0006 \\
\hline & LURB $_{t}$ & 6.6599 & 1.2396 & 5.3727 & 0.0000 \\
\hline & LFMD $_{\mathrm{t}}$ & 0.0677 & 0.0646 & 1.0483 & 0.3017 \\
\hline & Intercept & -31.8771 & 4.9651 & -6.4202 & 0.0000 \\
\hline \multirow[t]{5}{*}{ Israel } & $\mathrm{LGDPC}_{\mathrm{t}}$ & 0.3059 & 0.0459 & 6.6696 & 0.0000 \\
\hline & LGDPC $_{t}{ }^{2}$ & 0.0087 & 0.0062 & 1.4014 & 0.1704 \\
\hline & LURB $_{\mathrm{t}}$ & -61.8399 & 9.6866 & -6.3841 & 0.0000 \\
\hline & LFMD $_{\mathrm{t}}$ & 0.5507 & 0.1953 & 2.8197 & 0.0081 \\
\hline & Intercept & 272.6473 & 43.1324 & 6.3212 & 0.0000 \\
\hline \multirow[t]{5}{*}{ Kuwait } & $\mathrm{LGDPC}_{\mathrm{t}}$ & -9.9454 & 7.7571 & -1.2821 & 0.2082 \\
\hline & LGDPC $_{t}{ }^{2}$ & 0.5642 & 0.4351 & 1.2968 & 0.2032 \\
\hline & LURB $_{\mathrm{t}}$ & 2.3674 & 1.1915 & 1.9869 & 0.0548 \\
\hline & LFMD $_{t}$ & 0.1863 & 0.2579 & 0.7222 & 0.4749 \\
\hline & Intercept & -64.4897 & 40.7966 & -1.5808 & 0.1229 \\
\hline \multirow[t]{5}{*}{ Oman } & $\mathrm{LGDPC}_{\mathrm{t}}$ & -6.0544 & 4.6052 & -1.3147 & 0.1965 \\
\hline & $\mathrm{LGDPC}_{\mathrm{t}}{ }^{2}$ & 0.3884 & 0.2760 & 1.4073 & 0.1675 \\
\hline & LURB $_{\mathrm{t}}$ & 1.1235 & 1.3368 & 0.8404 & 0.4059 \\
\hline & LFMD $_{t}$ & 0.1112 & 0.3489 & 0.3187 & 0.7517 \\
\hline & Intercept & 18.6800 & 15.6349 & 1.1948 & 0.2396 \\
\hline \multirow[t]{5}{*}{ Qatar } & $\mathrm{LGDPC}_{\mathrm{t}}$ & 2.0038 & 4.3086 & 0.4651 & 0.6449 \\
\hline & LGDPC $_{t}{ }^{2}$ & -0.0864 & 0.1822 & -0.4741 & 0.6385 \\
\hline & LURB $_{t}$ & 4.1759 & 2.3214 & 1.7988 & 0.0812 \\
\hline & LFMD $_{\mathrm{t}}$ & -0.1043 & 0.1632 & -0.6390 & 0.5272 \\
\hline & Intercept & -28.8960 & 25.5757 & -1.1298 & 0.2667 \\
\hline \multirow[t]{5}{*}{ Saudi Arabia } & LGDPC $_{t}$ & 0.2786 & 2.1033 & 0.1324 & 0.8953 \\
\hline & $\mathrm{LGDPC}_{\mathrm{t}}{ }^{2}$ & -0.0026 & 0.0981 & -0.0264 & 0.9791 \\
\hline & LURB $_{\mathrm{t}}$ & 1.6821 & 0.6368 & 2.6416 & 0.0119 \\
\hline & LFMD $_{\mathrm{t}}$ & 0.3234 & 0.0881 & 3.6721 & 0.0007 \\
\hline & Intercept & 4.9499 & 11.0627 & 0.4474 & 0.6571 \\
\hline \multirow[t]{5}{*}{ UAE } & $\mathrm{LGDPC}_{\mathrm{t}}$ & -14.6625 & 6.4488 & -2.2737 & 0.0294 \\
\hline & $\mathrm{LGDPC}_{\mathrm{t}}{ }^{2}$ & 0.6227 & 0.2753 & 2.2621 & 0.0302 \\
\hline & $\mathrm{LURB}_{\mathrm{t}}$ & 9.2212 & 12.7174 & 0.7251 & 0.4734 \\
\hline & LFMD $_{\mathrm{t}}$ & -1.0503 & 0.7919 & -1.3263 & 0.1936 \\
\hline & Intercept & 828.0392 & 358.5755 & 2.3092 & 0.0271 \\
\hline
\end{tabular}

The results of the $\mathrm{LNGC}_{\mathrm{t}}$ model are presented in Table 2. The EKC is verified with positive and negative parameters of LGDPC $\mathrm{L}_{\mathrm{t}}$ and $\mathrm{LGDPC}_{\mathrm{t}}{ }^{2}$ in Iran, Kuwait, and the UAE. In Israel, both coefficients of $\mathrm{LGDPC}_{t}$ and $\mathrm{LGDPC}_{t}{ }^{2}$ are negative. Moreover, the effects of both $\mathrm{LGDPC}_{\mathrm{t}}$ and $\mathrm{LGDPC}_{\mathrm{t}}{ }^{2}$ were found to be statistically insignificant in the case of Iraq, Oman, Qatar, and Saudi Arabia. Urbanization positively affects the NGC in Iraq, Israel, and Saudi Arabia. So, the increasing urbanization is increasing natural gas consumption in these countries. Further, urbanization has a statistically insignificant effect on the natural gas consumption in Iran, Kuwait, Oman, Qatar, and the UAE. Moreover, FMD has statistically insignificant effects on natural gas consumption in all investigated countries. 
Table 2. Long-run results: $\mathrm{LNGC}_{\mathrm{t}}$ as the dependent variable.

\begin{tabular}{|c|c|c|c|c|c|}
\hline Country & Variable & Coefficient & Std. Error & $t$-Statistic & Prob. \\
\hline \multirow[t]{5}{*}{ Iran } & LGDPC $_{t}$ & 1.0688 & 0.4276 & 2.4993 & 0.0169 \\
\hline & $\mathrm{LGDPC}_{\mathrm{t}}{ }^{2}$ & -0.0255 & 0.0126 & -2.0205 & 0.0504 \\
\hline & LURB $_{\mathrm{t}}$ & 1.9994 & 1.7173 & 1.1642 & 0.2516 \\
\hline & LFMD $_{\mathrm{t}}$ & 0.1797 & 0.1983 & 0.9063 & 0.3705 \\
\hline & Intercept & -19.5223 & 4.8853 & -3.9961 & 0.0003 \\
\hline \multirow[t]{5}{*}{ Iraq } & LGDPC $_{t}$ & -2.7564 & 1.8385 & -1.4992 & 0.1428 \\
\hline & $\mathrm{LGDPC}_{\mathrm{t}}{ }^{2}$ & 0.1285 & 0.0828 & 1.5507 & 0.1300 \\
\hline & LURB $_{t}$ & 2.2189 & 1.0789 & 2.0567 & 0.0472 \\
\hline & LFMD $_{\mathrm{t}}$ & -0.1340 & 0.5782 & -0.2318 & 0.8181 \\
\hline & Intercept & -83.0931 & 40.0584 & -2.0743 & 0.0455 \\
\hline \multirow[t]{5}{*}{ Israel } & $\mathrm{LGDPC}_{\mathrm{t}}$ & -4.7235 & 1.1272 & -4.1906 & 0.0002 \\
\hline & LGDPC $_{t}{ }^{2}$ & -0.4627 & 0.2071 & -2.2336 & 0.0329 \\
\hline & $\mathrm{LURB}_{\mathrm{t}}$ & 1.3035 & 0.2989 & 4.3601 & 0.0001 \\
\hline & LFMD $_{\mathrm{t}}$ & 11.3513 & 7.5573 & 1.5020 & 0.1432 \\
\hline & Intercept & -5821.4500 & 1336.7330 & -4.3550 & 0.0001 \\
\hline \multirow[t]{5}{*}{ Kuwait } & $\mathrm{LGDPC}_{\mathrm{t}}$ & 7.1956 & 3.4390 & 2.09247 & 0.0437 \\
\hline & LGDPC $_{t}{ }^{2}$ & -0.3885 & 0.1961 & -1.9812 & 0.0555 \\
\hline & LURB $_{\mathrm{t}}$ & 0.4822 & 2.6419 & 0.1825 & 0.8562 \\
\hline & LFMD $_{t}$ & 0.1810 & 0.1621 & 1.1165 & 0.2718 \\
\hline & Intercept & -34.7152 & 19.8804 & -1.7462 & 0.0895 \\
\hline \multirow[t]{5}{*}{ Oman } & $\mathrm{LGDPC}_{\mathrm{t}}$ & -65.4054 & 135.5688 & -0.4825 & 0.6323 \\
\hline & $\mathrm{LGDPC}_{\mathrm{t}}{ }^{2}$ & 3.8377 & 8.0062 & 0.4793 & 0.6344 \\
\hline & LURB $_{\mathrm{t}}$ & 6.7788 & 17.9534 & 0.3776 & 0.7078 \\
\hline & LFMD $_{t}$ & 2.7040 & 5.5863 & 0.4840 & 0.6311 \\
\hline & Intercept & 240.0530 & 524.0307 & 0.4581 & 0.6495 \\
\hline \multirow[t]{5}{*}{ Qatar } & $\mathrm{LGDPC}_{\mathrm{t}}$ & 8.4326 & 9.9946 & 0.8437 & 0.4043 \\
\hline & LGDPC $_{t}{ }^{2}$ & -0.3673 & 0.4256 & -0.8632 & 0.3936 \\
\hline & LURB $_{t}$ & -0.7537 & 7.4239 & -0.1015 & 0.9197 \\
\hline & LFMD $_{\mathrm{t}}$ & 0.3803 & 0.5301 & 0.7175 & 0.4775 \\
\hline & Intercept & -43.3728 & 55.7132 & -0.7785 & 0.4412 \\
\hline \multirow[t]{5}{*}{ Saudi Arabia } & LGDPC $_{t}$ & -1.2618 & 1.4806 & -0.8522 & 0.4003 \\
\hline & $\mathrm{LGDPC}_{\mathrm{t}}{ }^{2}$ & 0.0587 & 0.0691 & 0.8497 & 0.4016 \\
\hline & LURB $_{\mathrm{t}}$ & 6.9055 & 0.8538 & 8.0876 & 0.0000 \\
\hline & LFMD $_{\mathrm{t}}$ & 0.0402 & 0.0784 & 0.5133 & 0.6111 \\
\hline & Intercept & -22.8053 & 9.1073 & -2.5041 & 0.0174 \\
\hline \multirow[t]{5}{*}{ UAE } & $\mathrm{LGDPC}_{\mathrm{t}}$ & 8.4453 & 4.8731 & 1.7330 & 0.0941 \\
\hline & LGDPC $_{t}{ }^{2}$ & -0.3667 & 0.2095 & -1.7508 & 0.0909 \\
\hline & $\mathrm{LURB}_{\mathrm{t}}$ & 2.0143 & 6.3555 & 0.3169 & 0.7536 \\
\hline & LFMD $_{\mathrm{t}}$ & 0.2330 & 0.2765 & 0.8425 & 0.4066 \\
\hline & Intercept & -493.5420 & 294.8169 & -1.6741 & 0.1053 \\
\hline
\end{tabular}

Table 3 shows the short-run results of the $\mathrm{LOC}_{\mathrm{t}}$ model, and the parameters of $\mathrm{ECT}_{\mathrm{t}-1}$ are corroborating the short-run relations in all countries' $\mathrm{LOC}_{\mathrm{t}}$ models. In the short run, the EKC is validated with positive and negative parameters of $\triangle \mathrm{LGDPC}_{\mathrm{t}}$ and $\triangle \mathrm{LGDPC}_{\mathrm{t}}{ }^{2}$ in Iran, Israel, and Iraq. A short-run, U-shaped relationship between oil consumption and growth was found in Kuwait and Qatar. In the UAE, the $\triangle \mathrm{LGDPC}_{t}$ and $\triangle \mathrm{LGDPC}_{\mathrm{t}}{ }^{2}$ have a statistically insignificant and positive effect on oil consumption, respectively. Moreover, the effects of $\triangle \mathrm{LGDPC}_{\mathrm{t}}$ and $\triangle \mathrm{LGDPC}_{\mathrm{t}}{ }^{2}$ on oil consumption were found to be statistically insignificant in Oman and Saudi Arabia. Urbanization has a short-run positive impact on the oil consumption in Iraq, Israel, Kuwait, and Qatar. Hence, increasing urbanization is accelerating the oil demand in the short run in these countries. Urbanization has a negative impact on oil consumption in Iran and Saudi Arabia. Further, urbanization could not affect the oil consumption in Oman and the UAE. FMD positively affects the oil consumption in Israel, Kuwait, and Saudi Arabia. Hence, increasing short-run financial 
development increases oil consumption in Israel, Kuwait, and Saudi Arabia. Further, FMD negatively affects oil consumption in the UAE. Hence, increasing financial development in the short run is reducing oil consumption in the UAE. However, FMD could not affect the oil consumption in Iran, Iraq, Oman, and Qatar.

Table 3. Short-run results: $\Delta \mathrm{LOC}_{\mathrm{t}}$ as the dependent variable.

\begin{tabular}{|c|c|c|c|c|c|}
\hline Country & Variable & Coefficient & Std. Error & $t$-Statistic & Prob. \\
\hline \multirow[t]{5}{*}{ Iran } & $\Delta$ LGDPC $_{\mathrm{t}}$ & 0.2693 & 0.1294 & 2.0807 & 0.0443 \\
\hline & $\Delta \mathrm{LGDPC}_{\mathrm{t}}^{2}$ & -0.0065 & 0.0038 & -1.6961 & 0.0981 \\
\hline & $\Delta \mathrm{LURB}_{\mathrm{t}}$ & -0.8093 & 0.4636 & -1.7458 & 0.0889 \\
\hline & $\triangle \mathrm{LFMD}_{\mathrm{t}}$ & -0.0281 & 0.0542 & -0.5181 & 0.6074 \\
\hline & $\mathrm{ECT}_{\mathrm{t}-1}$ & -0.4077 & 0.1129 & -3.6098 & 0.0009 \\
\hline \multirow[t]{6}{*}{ Iraq } & $\Delta \mathrm{LOC}_{\mathrm{t}-1}$ & 0.2993 & 0.1362 & 2.1970 & 0.0347 \\
\hline & $\Delta$ LGDPC $_{t}$ & 0.5003 & 0.1486 & 3.3663 & 0.0019 \\
\hline & $\Delta \mathrm{LGDPC}_{\mathrm{t}}{ }^{2}$ & -0.0181 & 0.0078 & -2.3224 & 0.0262 \\
\hline & $\Delta \mathrm{LURB}_{\mathrm{t}}$ & 5.1120 & 1.3629 & 3.7508 & 0.0006 \\
\hline & $\Delta \mathrm{LFMD}_{\mathrm{t}}$ & 0.0519 & 0.0482 & 1.0768 & 0.2890 \\
\hline & $\mathrm{ECT}_{\mathrm{t}-1}$ & -0.7676 & 0.1390 & -5.5221 & 0.0000 \\
\hline \multirow[t]{6}{*}{ Israel } & $\Delta \mathrm{LOC}_{\mathrm{t}-1}$ & 0.2550 & 0.1474 & 1.7306 & 0.0929 \\
\hline & $\Delta \mathrm{LGDPC}_{\mathrm{t}}$ & 1.1050 & 0.51878 & 2.1300 & 0.0407 \\
\hline & $\Delta \mathrm{LGDPC}_{\mathrm{t}}{ }^{2}$ & -0.0473 & 0.0255 & -1.8524 & 0.0729 \\
\hline & $\Delta \mathrm{LURB}_{\mathrm{t}}$ & 2.0337 & 0.7785 & 2.6124 & 0.0134 \\
\hline & $\Delta$ LFMD $_{\mathrm{t}}$ & 0.4147 & 0.1814 & 2.2864 & 0.0288 \\
\hline & $\mathrm{ECT}_{\mathrm{t}-1}$ & -0.7532 & 0.1527 & -4.9340 & 0.0000 \\
\hline \multirow[t]{5}{*}{ Kuwait } & $\Delta \mathrm{LGDPC}_{\mathrm{t}}$ & -3.0622 & 1.7663 & -1.7337 & 0.0918 \\
\hline & $\Delta \mathrm{LGDPC}_{\mathrm{t}}{ }^{2}$ & 0.2079 & 0.1067 & 1.9481 & 0.0595 \\
\hline & $\Delta \mathrm{LURB}_{\mathrm{t}}$ & 3.2179 & 1.58900 & 2.0251 & 0.0505 \\
\hline & $\Delta$ LFMD $_{\mathrm{t}}$ & 0.6404 & 0.1819 & 3.5201 & 0.0012 \\
\hline & $\mathrm{ECT}_{\mathrm{t}-1}$ & -0.3079 & 0.1296 & -2.3766 & 0.0231 \\
\hline \multirow[t]{5}{*}{ Oman } & $\Delta \mathrm{LGDPC}_{\mathrm{t}}$ & -2.2770 & 1.8578 & -1.2256 & 0.2279 \\
\hline & $\Delta \mathrm{LGDPC}_{\mathrm{t}}{ }^{2}$ & 0.1461 & 0.1124 & 1.2991 & 0.2017 \\
\hline & $\Delta \mathrm{LURB}_{\mathrm{t}}$ & 0.4225 & 0.4961 & 0.8518 & 0.3997 \\
\hline & $\triangle \mathrm{LFMD}_{\mathrm{t}}$ & 0.0418 & 0.1339 & 0.3122 & 0.7566 \\
\hline & $\mathrm{ECT}_{\mathrm{t}-1}$ & -0.3761 & 0.1239 & -3.0351 & 0.0043 \\
\hline \multirow[t]{6}{*}{ Qatar } & $\Delta \mathrm{LGDPC}_{\mathrm{t}}$ & -5.2363 & 2.6611 & -1.9677 & 0.0576 \\
\hline & $\Delta \mathrm{LGDPC}_{\mathrm{t}}^{2}$ & 0.2093 & 0.1124 & 1.8622 & 0.0715 \\
\hline & $\Delta \mathrm{LURB}_{\mathrm{t}}$ & 7.9581 & 3.3661 & 2.3642 & 0.0241 \\
\hline & $\Delta \mathrm{LURB}_{\mathrm{t}-1}$ & -7.6011 & 2.7123 & -2.8025 & 0.0084 \\
\hline & $\Delta$ LFMD $_{\mathrm{t}}$ & -0.0496 & 0.0746 & -0.6644 & 0.5110 \\
\hline & $\mathrm{ECT}_{\mathrm{t}-1}$ & -0.4754 & 0.1209 & -3.9320 & 0.0004 \\
\hline \multirow[t]{5}{*}{ Saudi Arabia } & $\Delta \mathrm{LGDPC}_{\mathrm{t}}$ & 0.1779 & 1.3301 & 0.1338 & 0.8943 \\
\hline & $\Delta \mathrm{LGDPC}_{\mathrm{t}}{ }^{2}$ & -0.0017 & 0.0626 & -0.0265 & 0.9790 \\
\hline & $\Delta \mathrm{LURB}_{\mathrm{t}}$ & -1.0743 & 0.4512 & -2.3809 & 0.0224 \\
\hline & $\Delta \mathrm{LFMD}_{\mathrm{t}}$ & 0.2065 & 0.0718 & 2.8767 & 0.0066 \\
\hline & $\mathrm{ECT}_{\mathrm{t}-1}$ & -0.6387 & 0.1540 & -4.1472 & 0.0002 \\
\hline \multirow[t]{7}{*}{ UAE } & $\Delta \mathrm{LOC}_{\mathrm{t}-1}$ & -0.2384 & 0.1522 & -1.5656 & 0.1267 \\
\hline & $\triangle$ LGDPC $_{\mathrm{t}}$ & -3.1377 & 1.1740 & -2.6727 & 0.0115 \\
\hline & $\Delta \mathrm{LGDPC}_{\mathrm{t}}{ }^{2}$ & 0.1333 & 0.0503 & 2.6497 & 0.0121 \\
\hline & $\Delta \mathrm{LURB}_{\mathrm{t}}$ & 1.9733 & 2.2980 & 0.8587 & 0.3965 \\
\hline & $\Delta \mathrm{LFMD}_{\mathrm{t}}$ & -0.4207 & 0.1666 & -2.5261 & 0.0164 \\
\hline & $\Delta \mathrm{LFMD}_{\mathrm{t}-1}$ & -0.3545 & 0.1594 & -2.2234 & 0.0329 \\
\hline & $\mathrm{ECT}_{\mathrm{t}-1}$ & -0.2140 & 0.0664 & -3.2241 & 0.0028 \\
\hline
\end{tabular}


Table 4. Short-run results: $\Delta \mathrm{LNGC}_{\mathrm{t}}$ as the dependent variable.

\begin{tabular}{|c|c|c|c|c|c|}
\hline Country & Variable & Coefficient & Std. Error & $t$-Statistic & Prob. \\
\hline \multirow[t]{5}{*}{ Iran } & $\Delta \mathrm{LGDPC}_{\mathrm{t}}$ & 0.7449 & 0.3506 & 2.1248 & 0.0402 \\
\hline & $\Delta \mathrm{LGDPC}_{\mathrm{t}}^{2}$ & -0.0178 & 0.0098 & -1.8210 & 0.0765 \\
\hline & $\Delta$ LURB $_{\mathrm{t}}$ & 1.3936 & 1.1770 & 1.1840 & 0.2438 \\
\hline & $\Delta \mathrm{FMD}_{\mathrm{t}}$ & 0.1254 & 0.1452 & 0.8629 & 0.3936 \\
\hline & $\mathrm{ECT}_{\mathrm{t}-1}$ & -0.6970 & 0.1574 & -4.4292 & 0.0001 \\
\hline \multirow[t]{5}{*}{ Iraq } & $\Delta \mathrm{LGDPC}_{\mathrm{t}}$ & 0.5306 & 0.577 & 0.9187 & 0.3645 \\
\hline & $\Delta \mathrm{LGDPC}_{\mathrm{t}}{ }^{2}$ & -0.0082 & 0.0270 & -0.3041 & 0.7628 \\
\hline & $\Delta \mathrm{LURB}_{\mathrm{t}}$ & 6.2888 & 2.4386 & 2.5789 & 0.0143 \\
\hline & $\Delta \mathrm{LFMD}_{\mathrm{t}}$ & -0.7267 & 0.5502 & -1.3208 & 0.1951 \\
\hline & $\mathrm{ECT}_{\mathrm{t}-1}$ & -0.2834 & 0.1005 & -2.8190 & 0.0079 \\
\hline \multirow[t]{7}{*}{ Israel } & $\Delta \mathrm{LGDPC}_{\mathrm{t}}$ & -31.8195 & 6.6429 & -4.7900 & 0.0000 \\
\hline & $\Delta \mathrm{LGDPC}_{\mathrm{t}}^{2}$ & 1.7265 & 0.3391 & 5.0914 & 0.0000 \\
\hline & $\Delta \mathrm{LGDPC}_{\mathrm{t}-1}{ }^{2}$ & -0.2335 & 0.0776 & -3.0091 & 0.0052 \\
\hline & $\Delta \mathrm{LURB}_{\mathrm{t}}$ & -10.0227 & 10.1003 & -0.9923 & 0.3287 \\
\hline & $\triangle \mathrm{LFMD}_{\mathrm{t}}$ & 1.12398 & 2.5127 & 0.4473 & 0.6578 \\
\hline & $\Delta \mathrm{LFMD}_{\mathrm{t}-1}$ & -5.5934 & 2.2182 & -2.5216 & 0.0170 \\
\hline & $\mathrm{ECT}_{\mathrm{t}-1}$ & -0.3765 & 0.1105 & -3.4071 & 0.0018 \\
\hline \multirow[t]{5}{*}{ Kuwait } & $\triangle \mathrm{LGDPC}_{\mathrm{t}}$ & 13.7917 & 3.6556 & 3.7728 & 0.0006 \\
\hline & $\Delta \mathrm{LGDPC}_{\mathrm{t}}{ }^{2}$ & -0.7316 & 0.2197 & -3.3307 & 0.0021 \\
\hline & $\Delta \mathrm{LURB}_{\mathrm{t}}$ & 0.4097 & 2.2433 & 0.1827 & 0.8561 \\
\hline & $\Delta \mathrm{LFMD}_{\mathrm{t}}$ & 0.5093 & 0.3054 & 1.6676 & 0.1043 \\
\hline & $\mathrm{ECT}_{\mathrm{t}-1}$ & -0.8497 & 0.1472 & -5.7718 & 0.0000 \\
\hline \multirow[t]{5}{*}{ Oman } & $\Delta \mathrm{LGDPC}_{\mathrm{t}}$ & -13.5593 & 18.5098 & -0.7326 & 0.4683 \\
\hline & $\Delta \mathrm{LGDPC}_{\mathrm{t}}{ }^{2}$ & 0.7956 & 1.0998 & 0.7234 & 0.4738 \\
\hline & $\Delta \mathrm{LURB}_{\mathrm{t}}$ & 1.4053 & 3.6051 & 0.3898 & 0.6988 \\
\hline & $\Delta \mathrm{LFMD}_{\mathrm{t}}$ & 0.5606 & 0.9643 & 0.5813 & 0.5645 \\
\hline & $\mathrm{ECT}_{\mathrm{t}-1}$ & -0.2073 & 0.1768 & -1.1726 & 0.2482 \\
\hline \multirow[t]{5}{*}{ Qatar } & $\Delta \mathrm{LGDPC}_{\mathrm{t}}$ & 3.0080 & 3.1606 & 0.9517 & 0.3474 \\
\hline & $\Delta \mathrm{LGDPC}_{\mathrm{t}}{ }^{2}$ & -0.1218 & 0.1336 & -0.9118 & 0.3678 \\
\hline & $\Delta \mathrm{LURB}_{\mathrm{t}}$ & -0.2499 & 2.4020 & -0.1040 & 0.9177 \\
\hline & $\Delta \mathrm{LFMD}_{\mathrm{t}}$ & 0.1261 & 0.1497 & 0.8423 & 0.4050 \\
\hline & $\mathrm{ECT}_{\mathrm{t}-1}$ & -0.3316 & 0.1388 & -2.3882 & 0.0221 \\
\hline \multirow[t]{7}{*}{ Saudi Arabia } & $\triangle \mathrm{LGDPC}_{\mathrm{t}}$ & -1.0526 & 1.2342 & -0.8528 & 0.3999 \\
\hline & $\Delta \mathrm{LGDPC}_{\mathrm{t}}^{2}$ & 0.0597 & 0.0575 & 1.0382 & 0.3067 \\
\hline & $\Delta \mathrm{LGDPC}_{\mathrm{t}-1}{ }^{2}$ & 0.0053 & 0.0040 & 1.3422 & 0.1887 \\
\hline & $\Delta \mathrm{LURB}_{\mathrm{t}}$ & 7.6173 & 8.3888 & 0.9080 & 0.3704 \\
\hline & $\Delta \mathrm{LURB}_{\mathrm{t}-1}$ & 12.2664 & 7.9411 & 1.5447 & 0.1320 \\
\hline & $\Delta$ LFMD $_{\mathrm{t}}$ & 0.0336 & 0.0650 & 0.5167 & 0.6088 \\
\hline & $\mathrm{ECT}_{\mathrm{t}-1}$ & -0.8342 & 0.1287 & -6.4806 & 0.0000 \\
\hline \multirow[t]{10}{*}{ UAE } & $\Delta \mathrm{LNGC}_{\mathrm{t}-1}$ & -0.1982 & 0.1467 & -1.3509 & 0.1876 \\
\hline & $\Delta \mathrm{LGDPC}_{\mathrm{t}}$ & 27.0364 & 15.0300 & 1.7988 & 0.0828 \\
\hline & $\Delta \mathrm{LGDPC}_{\mathrm{t}-1}$ & -23.1295 & 11.5749 & -1.9983 & 0.0555 \\
\hline & $\Delta \mathrm{LGDPC}_{\mathrm{t}}^{2}$ & -1.1366 & 0.6360 & -1.7871 & 0.0848 \\
\hline & $\Delta \mathrm{LGDPC}_{\mathrm{t}-1}{ }^{2}$ & 0.9850 & 0.4932 & 1.9970 & 0.0556 \\
\hline & $\Delta$ LURB $_{\mathrm{t}}$ & -1.7493 & 16.4783 & -0.1062 & 0.9162 \\
\hline & $\Delta \mathrm{LURB}_{\mathrm{t}-1}$ & -8.6703 & 14.9209 & -0.5811 & 0.5658 \\
\hline & $\Delta$ LFMD $_{\mathrm{t}}$ & 0.8835 & 0.3269 & 2.7022 & 0.0116 \\
\hline & $\Delta \mathrm{LFMD}_{\mathrm{t}-1}$ & -0.3435 & 0.2660 & -1.2914 & 0.2071 \\
\hline & $\mathrm{ECT}_{\mathrm{t}-1}$ & -0.3604 & 0.1062 & -3.3939 & 0.0021 \\
\hline
\end{tabular}

Table 4 presents the $\mathrm{LNGC}_{\mathrm{t}}$ model's short-run results, and the parameters of $\mathrm{ECT}_{\mathrm{t}-1}$ are corroborating the short-run relations in all countries' $\mathrm{LOC}_{\mathrm{t}}$ models, except for Oman. The EKC is confirmed in Iran, Kuwait, and the UAE. The coefficients of $\triangle$ LGDPC $_{t}$ and $\triangle \mathrm{LGDPC}_{\mathrm{t}}{ }^{2}$ are statistically insignificant in Iraq, Oman, Qatar, and Saudi Arabia. 
In Table 4, urbanization shows the short-run positive effect on NGC in Iraq. Hence, increasing urbanization is accelerating NGS in Iraq. Except for Iraq, urbanization has not affected NGC in all the investigated countries. The one-year lag of FMD has a negative effect on NGC in Israel. Moreover, FMD has a short-run positive effect on NGC in the UAE. Hence, increasing short-run financial development is increasing the natural gas consumption in the UAE. FMD has a statistically insignificant effect on natural gas consumption in the rest of the countries.

In summary of the results, the panel unit root tests validated that all panel series are stationary at first differences. Cointegration tests corroborate the long-run relationships in the hypothesized models of oil consumption and NGC. The long-run results confirm the presence of the energy-EKC in the panel models of both oil consumption and NGC in eight Middle East countries. Further, urbanization has a positive effect on both oil consumption and NGC. FMD shows a positive effect on oil consumption in most of the investigated panel techniques. However, FMD has a negative effect on NGC in one of three panel estimation techniques. We have also tested the country-specific time series models to gain a deeper insight into the individual country's results. In the unit root analyses, we find the first difference stationary series in the models of Iran, Israel, Qatar, and Saudi Arabia. However, a mixed order of integration is found in the models of Iraq, Oman, Israel, and the UAE. Moreover, long- and short-run relationships were found in all countries' oil and natural gas consumption models, except for Oman's natural gas consumption model. In the long run, the evidence of the energy-EKC is found in the oil consumption models of Iran and Iraq. The energy-EKC hypothesis is also found in the natural gas consumption models of Iran, Kuwait, and the UAE. Moreover, a U-shaped relation between oil consumption and economic growth is corroborated in the UAE. In the short run, the energy-EKC hypothesis is found in the oil consumption models of Iran, Iraq, and Israel; it is also validated in the NGC models of Iran, Kuwait, and the UAE. Moreover, a U-shaped relationship between oil consumption and economic growth is corroborated in Kuwait and Qatar. In the long run, urbanization has a positive effect on oil consumption in Iraq, Kuwait, Saudi Arabia, and Qatar. Moreover, urbanization shows a positive effect on NGC in Iraq, Israel, and Saudi Arabia. Conversely, urbanization has a negative effect on oil consumption in Israel. In the short run, urbanization has a positive effect on oil consumption in Iraq, Israel, Kuwait, and Qatar. Further, it has a positive effect on NGC in Iraq. Conversely, urbanization has a negative effect on oil consumption in Iran and Saudi Arabia. In the long run, FMD has a positive effect on oil consumption in Israel and Saudi Arabia. In the short run, FMD shows a positive effect on oil consumption in Israel, Kuwait, and Saudi Arabia. Further, it has a positive effect on NGS in the UAE. Conversely, FMD has a negative effect on oil consumption in the UAE. Moreover, it has a negative effect on NGC in Israel.

\section{Conclusions}

The present study has investigated the energy-EKC hypothesis in the relationship of energy consumption and economic growth in panel and individual country analyses of eight Middle East countries, using the period 1975-2019. To test this relationship, we utilized two proxies of energy consumption, i.e., oil and natural gas consumption. Urbanization and FMD were utilized as the control variables. The energy-EKC hypothesis is corroborated in the long-run relationship between economic growth and oil consumption in Iran and Iraq. Hence, the increasing economic growth of these two countries may have pleasant environmental consequences by reducing oil consumption after a threshold point of economic growth. On the other hand, a U-shaped long-run relationship is found between economic growth and oil consumption in the UAE. Hence, the increasing economic growth of the UAE has negative environmental consequences because of increasing oil consumption. Therefore, the UAE's economic growth is not environmentally sustainable. Moreover, the energy-EKC hypothesis is corroborated in the natural gas consumption models of Iran, Kuwait, and the UAE. After a threshold point, these three countries' increasing economic growth can reduce natural gas consumption. Hence, these countries 
are enjoying sustainable economic growth by reducing natural gas consumption. The energy-EKC is corroborated in four out of eight investigated countries either in the oil or natural gas consumption models. The existing literature has corroborated the existence of the energy-EKC hypothesis [10,13-15] and the non-existence of the energy-EKC hypothesis $[11,12,16]$. Moreover, our results confirm that urbanization has a long-run positive effect on oil consumption in Iraq, Kuwait, Saudi Arabia, and Qatar. Moreover, urbanization has a long-run positive effect on the NGC in Iraq, Israel, and Saudi Arabia. Hence, urbanization accelerates the oil consumption in four out of eight investigated countries, and it increases the NGC in three out of eight investigated countries. This result follows the standard theory that urbanization may increase the demand for such products that need extensive energy. Middle East countries are major energy consumers of oil and natural gas and are also highly urbanized. Hence, increasing urbanization would accelerate oil and natural gas consumption. Therefore, the government of Middle East countries should discourage urbanization to reduce energy consumption. This finding is in line with the existing empirical literature $[13,15]$. On the other hand, we find that urbanization has a long-term negative effect on Israel's oil consumption. This result is in line with the empirical findings of Li et al. [16]. This result also realizes the fact of switching Israel's energy demand from oil consumption to renewable energy sources since 2001. Moreover, Israel is the largest renewable energy consumer in the Middle East region compared to other Middle East countries. Hence, urbanization in Israel is environmentally sustainable by reducing oil consumption. Further, it may also reflect that the demand for oil consumption has switched to natural gas consumption as urbanization has positively affected natural gas consumption in Israel. FMD has a long-run positive effect on oil consumption in Israel and Saudi Arabia. This result realizes the fact that both countries are financing small and medium enterprises, which have a lesser capacity for cleaner technology installation and are increasing oil demand. Moreover, the significant growth of personal banking in these countries raises the demand for energy consumption as well. Hence, increasing FMD in Israel and Saudi Arabia has environmental consequences because of increasing oil consumption. Hence, excessive FMD should be checked out to ensure sustainable growth in these countries. On the other hand, FMD could not affect oil consumption in six out of eight investigated countries. It also does not affect natural gas consumption in all investigated countries. This result matches the empirical findings in the literature $[19,21]$, which did not find any causal relationships between FMD and pollution emissions.

Based on long-run, country-specific results, we recommend Iraq, Kuwait, Saudi Arabia, and Qatar to control urbanization to reduce oil consumption. Moreover, we suggest that Iraq, Israel, and Saudi Arabia should control urbanization to reduce natural gas consumption. We recommend that Israel and Saudi Arabia should discourage the financial sector's loans, leading to higher oil consumption. Financial and non-financial benefits should be offered in the investigated countries to support renewable energy consumption.

Researchers already have investigated the EKC hypothesis in the relationship between economic growth and pollution emissions in a number of countries of the MENA region $[19,23]$. The present study contributes to the existing stream of literature by investigating about the energy-EKC in the relationship between economic growth and two energy consumption proxies, namely, oil consumption and natural gas consumption, in eight Middle East countries, using the maximum available time sample of 1975-2019. Moreover, testing the effect of FMD in the energy-EKC hypothesis is also unique in this present study, which has never been tested before in any energy-EKC study. However, the present study could not focus on all Middle East countries. Hence, future research may expand the scope of the study by collecting the data from the Middle East countries' internal sources and including other regional-specific relevant proxies in the energy-EKC hypothesis testing. 
Author Contributions: Conceptualization, H.M. and N.M.; methodology, H.M.; software, H.M.; validation, H.M. and N.M.; formal analysis, N.M.; investigation, H.M. and N.M.; data curation, H.M.; writing-original draft preparation, H.M. and M.S.H.; writing—review and editing, N.M. and M.S.H.; supervision, H.M.; project administration, H.M. All authors have read and agreed to the published version of the manuscript.

Funding: This research received no external funding.

Institutional Review Board Statement: Not applicable.

Informed Consent Statement: Not applicable.

Data Availability Statement: The data are publicly available [17,49].

Conflicts of Interest: The authors declare no conflict of interest.

\section{Appendix A}

Table A1. Panel unit root test.

\begin{tabular}{|c|c|c|c|c|c|c|}
\hline \multirow{2}{*}{ Variable } & \multicolumn{2}{|c|}{ IPS } & \multicolumn{2}{|c|}{ LLC } & \multicolumn{2}{|c|}{ Fisher-ADF } \\
\hline & $\mathrm{C}$ & C\&T & $\mathrm{C}$ & $C \& T$ & $\mathrm{C}$ & $\mathrm{C} \& \mathrm{~T}$ \\
\hline \multicolumn{7}{|c|}{ Level } \\
\hline $\mathrm{LOC}_{\text {it }}$ & -0.5019 & -0.5762 & -1.0559 & -0.9203 & -0.4895 & -0.6467 \\
\hline $\mathrm{LNGC}_{\text {it }}$ & -0.8667 & -1.1156 & -0.7661 & -0.7206 & -1.2532 & -0.8152 \\
\hline LGDPC $_{i t}$ & 0.5660 & -0.0531 & -1.1156 & -0.2171 & 0.6243 & -0.0972 \\
\hline LURB $_{\text {it }}$ & -0.3940 & -0.8774 & -1.6615 & -1.4184 & -1.2964 & -1.0812 \\
\hline LFMD $_{\text {it }}$ & -0.5280 & -1.0299 & -0.3603 & -1.2575 & -0.4697 & -0.8347 \\
\hline \multicolumn{7}{|c|}{ First Difference } \\
\hline$\Delta \mathrm{LOC}_{\mathrm{it}}$ & $-11.4033^{* *}$ & $-10.5881^{* *}$ & -10.8110 ** & $-10.5174^{* *}$ & $-10.3250 * *$ & $-9.2038^{* *}$ \\
\hline$\Delta \mathrm{LNGC}_{\mathrm{it}}$ & $-10.0768^{* *}$ & $-9.4862^{* *}$ & $-10.0385^{* *}$ & $-9.6337^{* *}$ & $-9.2439 * *$ & $-8.3785^{* *}$ \\
\hline$\Delta$ LGDPC $_{i t}$ & $-7.2798^{* *}$ & $-6.2337^{* *}$ & $-5.6516^{* *}$ & $-5.5698 * *$ & $-6.9998^{* *}$ & $-5.8915^{* *}$ \\
\hline$\Delta$ LURB $_{\text {it }}$ & $-2.5657 * *$ & $-4.1100^{* *}$ & $-3.9457 * *$ & $-2.3644^{*}$ & $-2.6516^{* *}$ & $-8.1518^{* *}$ \\
\hline$\Delta \mathrm{LFMD}_{\mathrm{it}}$ & $-9.8139 * *$ & $-8.7922 * *$ & $-9.3740 * *$ & $-9.0642^{* *}$ & $-9.0285^{* *}$ & $-7.8291 * *$ \\
\hline
\end{tabular}

Note: ${ }^{*}$ and ${ }^{* *}$ show stationarity at $5 \%$ and $1 \%$ significant level.

Table A2. Panel cointegration: $\mathrm{LOC}_{\mathrm{it}}$ as the dependent variable.

\begin{tabular}{|c|c|c|c|c|}
\hline & Stat. & $p$-Value & Weighed Stat. & $p$-Value \\
\hline \multicolumn{5}{|c|}{ Pedroni Test } \\
\hline \multicolumn{5}{|c|}{ Within-dimension } \\
\hline Panel-v & 0.6263 & 0.2655 & 0.8968 & 0.1849 \\
\hline Panel-rho & -0.0828 & 0.4670 & -0.8017 & 0.2114 \\
\hline Panel-PP & -1.0281 & 0.1520 & -1.9878 & 0.0234 \\
\hline Panel-ADF & -0.9374 & 0.1743 & -2.3278 & 0.0100 \\
\hline \multicolumn{5}{|c|}{ Between-dimension } \\
\hline Group-rho & -0.05629 & 0.4776 & & \\
\hline Group-PP & -1.8154 & 0.0347 & & \\
\hline Group-ADF & -2.65458 & 0.0040 & & \\
\hline \multicolumn{5}{|c|}{ Kao Test } \\
\hline $\mathrm{ADF}$ & -3.5639 & 0.0002 & & \\
\hline Residual variance & 0.0185 & & & \\
\hline
\end{tabular}


Table A2. Cont.

\begin{tabular}{ccccc}
\hline & Stat. & $p$-Value & Weighed Stat. & $p$-Value \\
\hline \multicolumn{5}{c}{ Fisher-Johansen Test } \\
\hline Co-integrating Equations & Trace test & Max-Eigen test \\
\hline None & 112.7 & 0.0000 & 55.55 & 0.0000 \\
At most 1 & 67.87 & 0.0000 & 39.09 & 0.0011 \\
At most 2 & 40.23 & 0.0007 & 25.29 & 0.0650 \\
At most 3 & 28.46 & 0.0279 & 19.64 & 0.2369 \\
At most 4 & 37.66 & 0.0017 & 37.66 & 0.0017 \\
\hline \multicolumn{5}{c}{ Westerlund Test } \\
Statistic & Value & Z-value & \\
Gt & -4.021 & -3.607 & 0.000 & \\
Ga & -6.012 & 3.714 & 1.000 & \\
Pt & -8.605 & -1.174 & 0.120 & \\
Pa & -9.069 & 1.583 & 0.943 & \\
\hline
\end{tabular}

Table A3. Panel cointegration: $\mathrm{LNGC}_{\mathrm{it}}$ as the dependent variable.

\begin{tabular}{|c|c|c|c|c|}
\hline & Stat. & $p$-Value & Weighed Stat. & $p$-Value \\
\hline \multicolumn{5}{|c|}{ Pedroni Test } \\
\hline \multicolumn{5}{|c|}{ Within-dimension } \\
\hline Panel-v & 2.9080 & 0.0018 & 1.3724 & 0.0850 \\
\hline Panel-rho & -1.0310 & 0.1513 & -1.9182 & 0.0275 \\
\hline Panel-PP & -3.0620 & 0.0011 & -3.4984 & 0.0002 \\
\hline Panel-ADF & -3.7187 & 0.0001 & -4.4622 & 0.0000 \\
\hline \multicolumn{5}{|c|}{ Between-dimension } \\
\hline Group-rho & -0.8819 & 0.1889 & & \\
\hline Group-PP & -3.2446 & 0.0006 & & \\
\hline Group-ADF & -4.5640 & 0.0000 & & \\
\hline \multicolumn{5}{|c|}{ Kao Test } \\
\hline ADF & -4.1035 & 0.0000 & & \\
\hline Residual variance & 0.4663 & & & \\
\hline \multicolumn{5}{|c|}{ Fisher-Johansen Test } \\
\hline Co-integrating Equations & Trace test & & Max-Eigen test & \\
\hline None & 151.80 & 0.0000 & 91.78 & 0.0000 \\
\hline At most 1 & 76.84 & 0.0000 & 35.60 & 0.0033 \\
\hline At most 2 & 51.82 & 0.0000 & 28.82 & 0.0252 \\
\hline At most 3 & 36.87 & 0.0022 & 29.73 & 0.0195 \\
\hline At most 4 & 32.12 & 0.0096 & 32.12 & 0.0096 \\
\hline \multicolumn{5}{|c|}{ Westerlund Test } \\
\hline Statistic & Value & Z-value & $p$-value & \\
\hline $\mathrm{Gt}$ & -8.916 & -19.079 & 0.0000 & \\
\hline $\mathrm{Ga}$ & -8.760 & 0.445 & 0.6720 & \\
\hline $\mathrm{Pt}$ & -7.579 & -2.373 & 0.0090 & \\
\hline $\mathrm{Pa}$ & -11.669 & -2.149 & 0.0160 & \\
\hline
\end{tabular}


Table A4. Long- and short-run results.

\begin{tabular}{|c|c|c|c|c|c|c|c|c|}
\hline \multirow[t]{2}{*}{ Variable } & \multicolumn{4}{|c|}{$\mathrm{LOC}_{\mathrm{it}}$} & \multicolumn{4}{|c|}{ LNGC $_{\text {it }}$} \\
\hline & Coefficient & Std. Error & $t$-Statistic & $p$-Value & Coefficient & Std. Error & $t$-Statistic & $p$-Value \\
\hline \multicolumn{9}{|c|}{ FMOLS } \\
\hline LGDPC $_{\text {it }}$ & 0.5950 & 0.1301 & 4.5662 & 0.0000 & 9.6012 & 3.0561 & 3.1417 & 0.0018 \\
\hline LGDPC $_{i t}{ }^{2}$ & -0.0606 & 0.0182 & -3.3274 & 0.0010 & -0.5741 & 0.1454 & -3.9492 & 0.0001 \\
\hline LURB $_{\text {it }}$ & 0.8313 & 0.0560 & 14.9442 & 0.0000 & 5.0356 & 1.0076 & 4.9976 & 0.0000 \\
\hline LFMD $_{\text {it }}$ & 0.1046 & 0.0143 & 7.3373 & 0.0000 & -0.8132 & 0.3136 & -2.5932 & 0.0099 \\
\hline \multicolumn{9}{|c|}{ DOLS } \\
\hline LGDPC $_{\text {it }}$ & 0.5731 & 0.1535 & 3.7343 & 0.0002 & 15.6651 & 5.4287 & 2.8856 & 0.0043 \\
\hline $\mathrm{LGDPC}_{\mathrm{it}}{ }^{2}$ & -0.0238 & 0.0067 & -3.5666 & 0.0004 & -0.8751 & 0.2410 & -3.6310 & 0.0003 \\
\hline $\mathrm{LURB}_{\text {it }}$ & 1.0377 & 0.6055 & 1.7139 & 0.0879 & 12.7388 & 3.3369 & 3.8176 & 0.0002 \\
\hline LFMD $_{\text {it }}$ & 0.1831 & 0.0697 & 2.6267 & 0.0092 & 0.2699 & 1.0132 & 0.2664 & 0.7902 \\
\hline \multicolumn{9}{|c|}{ PMG } \\
\hline & & & & Long run & & & & \\
\hline LGDPC $_{\text {it }}$ & 0.1919 & 0.0777 & 2.4677 & 0.0142 & 2.2245 & 0.4728 & 4.7046 & 0.0000 \\
\hline $\mathrm{LGDPC}_{\mathrm{it}}{ }^{2}$ & -0.0074 & 0.0032 & -2.3283 & 0.0206 & -0.1034 & 0.0226 & -4.5731 & 0.0000 \\
\hline LURB $_{\text {it }}$ & 1.5988 & 0.4595 & 3.4796 & 0.0006 & 4.7914 & 1.2737 & 3.7617 & 0.0002 \\
\hline LFMD $_{\text {it }}$ & 0.0263 & 0.0490 & 0.5371 & 0.5916 & 0.1268 & 0.0879 & 1.4429 & 0.1501 \\
\hline \multicolumn{9}{|c|}{ Short run } \\
\hline $\mathrm{ECT}_{\mathrm{t}-1}$ & -0.2794 & 0.0579 & -4.8245 & 0.0000 & -0.2749 & 0.0936 & -2.9375 & 0.0036 \\
\hline LGDPC $_{\text {it }}$ & -3.9840 & 3.2422 & -1.2288 & 0.2202 & -4.0366 & 3.6233 & -1.1140 & 0.2661 \\
\hline LGDPC $_{i t}^{2}$ & 0.1838 & 0.1396 & 1.3164 & 0.1892 & 0.2041 & 0.1904 & 1.0718 & 0.2846 \\
\hline LURB $_{\text {it }}$ & 15.9198 & 14.1700 & 1.1235 & 0.2622 & 19.6948 & 19.7832 & 0.9955 & 0.3203 \\
\hline LFMD $_{\text {it }}$ & 0.0506 & 0.1664 & 0.3041 & 0.7613 & -0.4004 & 0.4744 & -0.8440 & 0.3993 \\
\hline Intercept & -2.1068 & 0.4628 & -4.5523 & 0.0000 & -8.7984 & 3.0393 & -2.8949 & 0.0041 \\
\hline
\end{tabular}

Table A5. Ng-Perron results.

\begin{tabular}{|c|c|c|c|c|c|}
\hline \multirow{2}{*}{ Country } & \multirow{2}{*}{ Variable } & \multicolumn{2}{|c|}{ Level } & \multicolumn{2}{|c|}{ First Difference } \\
\hline & & $\mathrm{C}$ & $\mathbf{T}$ & $\mathrm{C}$ & $\mathbf{T}$ \\
\hline Iran & $\begin{array}{c}\text { LOC }_{t} \\
\text { LNGC }_{t} \\
\text { LGDPC }_{t} \\
\text { LURB }_{t} \\
\text { LFMD }_{t}\end{array}$ & $\begin{array}{c}-1.0367 \\
1.0059 \\
1.0530 \\
1.2789 \\
1.0806\end{array}$ & $\begin{array}{c}-7.1080 \\
-11.5911 \\
-5.6616 \\
-5.8828 \\
-2.6533\end{array}$ & $\begin{array}{l}-16.6341^{* * *} \\
-20.0875^{* * *} \\
-15.8883^{* * *} \\
-8.4506^{*} \\
-19.5990^{* * *}\end{array}$ & $\begin{array}{l}-19.8688 \text { ** } \\
-20.1532 \\
-17.1208 \\
-16.3733^{*} \\
-19.8725^{* *}\end{array}$ \\
\hline Iraq & $\begin{array}{c}\text { LOC }_{t} \\
\text { LNGC }_{t} \\
\text { LGDPC }_{t} \\
\text { LURB }_{t} \\
\text { LFMD }_{t}\end{array}$ & $\begin{array}{l}-1.0957 \\
-3.7860 \\
-0.7823 \\
-0.0864 \\
-2.8137 \\
\end{array}$ & $\begin{array}{c}-4.0878 \\
-4.7801 \\
-13.8173 \\
-3.1837 \\
-15.9457 * \\
\end{array}$ & $\begin{array}{c}-20.3488^{* * *} \\
-18.4093^{* * *} \\
-10.2329^{* *} \\
-6.9355^{*} \\
-11.3332^{* *}\end{array}$ & $\begin{array}{l}-53.2711^{* * *} \\
-19.2108^{* *} \\
-15.6057^{*} \\
-14.9239^{*} \\
-19.5686^{* *}\end{array}$ \\
\hline Israel & $\begin{array}{c}\text { LOC }_{t} \\
\text { LNGC }_{t} \\
\text { LGDPC }_{t} \\
\text { LURB }_{t} \\
\text { LFMD }_{t}\end{array}$ & $\begin{array}{c}-3.1667 \\
-2.6187 \\
-1.2922 \\
0.6565 \\
-1.3371\end{array}$ & $\begin{array}{c}-5.5197 \\
-5.9866 \\
-15.8184 \\
-3.1602 \\
-5.2898\end{array}$ & $\begin{array}{c}-21.2312^{* * *} \\
-21.4329^{* * *} \\
-6.0449^{*} \\
-7.7431^{*} \\
-25.1067^{* * *}\end{array}$ & $\begin{array}{l}-21.4578^{* *} \\
-21.4757^{* *} \\
-21.1076^{* *} \\
-16.5910^{*} \\
-27.5018^{* * *}\end{array}$ \\
\hline Kuwait & $\begin{array}{c}\text { LOC }_{t} \\
\text { LNGC }_{t} \\
\text { LGDPC }_{t} \\
\text { LURB }_{t} \\
\text { LFMD }_{t}\end{array}$ & $\begin{array}{l}-4.4962 \\
-3.3226 \\
-4.0907 \\
-0.1200 \\
-0.0265\end{array}$ & $\begin{array}{c}-6.4331 \\
-4.9735 \\
-12.0389 \\
-3.3554 \\
-0.0293 \\
\end{array}$ & $\begin{array}{c}-21.3902^{* *} \\
-21.2848^{* * *} \\
-19.6653^{* * *} \\
-6.5454^{*} \\
-10.5323^{* *}\end{array}$ & $\begin{array}{l}-21.3902 \\
-21.2328 \\
-19.648 \\
-16.9342^{* *} \\
-14.3291^{*}\end{array}$ \\
\hline Oman & $\begin{array}{c}\text { LOC }_{t} \\
\text { LNGC }_{t} \\
\text { LGDPC }_{t} \\
\text { LURB }_{t} \\
\text { LFMD }_{t}\end{array}$ & $\begin{array}{c}-3.6036 \\
-1.0783 \\
0.3623 \\
-0.0143 \\
1.1169\end{array}$ & $\begin{array}{l}-10.4600 \\
-1.9595 \\
-6.1260 \\
-5.3615 \\
-15.0955 *\end{array}$ & $\begin{array}{c}-21.3113^{* * *} \\
-5.7167^{*} \\
-20.9088^{* * *} \\
-1.5879^{* * *} \\
-19.0206^{* *}\end{array}$ & $\begin{array}{l}-21.17600^{* *} \\
-14.3332^{*} \\
-21.3433^{* *} \\
-5.4288 \\
-19.6310^{* *}\end{array}$ \\
\hline
\end{tabular}


Table A5. Cont.

\begin{tabular}{|c|c|c|c|c|c|}
\hline \multirow{2}{*}{ Country } & \multirow{2}{*}{ Variable } & \multicolumn{2}{|c|}{ Level } & \multicolumn{2}{|c|}{ First Difference } \\
\hline & & $\mathrm{C}$ & $\mathbf{T}$ & $\mathrm{C}$ & $\mathrm{T}$ \\
\hline Qatar & $\begin{array}{c}\text { LOC }_{t} \\
\text { LNGC }_{t} \\
\text { LGDPC }_{t} \\
\text { LURB }_{t} \\
\text { LFMD }_{t}\end{array}$ & $\begin{array}{c}-1.3229 \\
-9.7476^{* *} \\
-0.2450 \\
-6.3326^{*} \\
0.5021\end{array}$ & $\begin{array}{l}-5.4363 \\
-9.6165 \\
-2.8245 \\
-7.7273 \\
-6.2998\end{array}$ & $\begin{array}{l}-18.4751^{* * *} \\
-13.7065^{* *} \\
-17.8824^{* * *} \\
-38.4032^{* * *} \\
-21.4447^{* * *}\end{array}$ & $\begin{array}{l}-21.0986^{* *} \\
-18.9782^{* *} \\
-19.0434^{* *} \\
-69.3113^{* *} \\
-21.4362^{* *}\end{array}$ \\
\hline $\begin{array}{l}\text { Saudi } \\
\text { Arabia }\end{array}$ & $\mathrm{LOC}_{\mathrm{t}}$ & -0.8016 & -8.8484 & $-7.3051 *$ & $-20.6032^{* *}$ \\
\hline & $\begin{array}{c}\text { LNGC }_{t} \\
\text { LGDPC }_{t} \\
\text { LURB }_{t} \\
\text { LFMD }_{t}\end{array}$ & $\begin{array}{c}-0.2751 \\
0.0503 \\
0.6540 \\
0.9924\end{array}$ & $\begin{array}{l}-4.4441 \\
-8.6820 \\
-1.9123 \\
-4.5439\end{array}$ & $\begin{array}{c}-8.2284^{* *} \\
-13.6074^{* *} \\
-7.3234^{*} \\
-21.2109^{* * *}\end{array}$ & $\begin{array}{l}-17.1687 \text { * } \\
-16.2763 \\
-18.9861 \\
-21.3394^{* *}\end{array}$ \\
\hline UAE & $\begin{array}{c}\text { LOC }_{t} \\
\text { LNGC }_{t} \\
\text { LGDPC }_{t} \\
\text { LURB }_{t} \\
\text { LFMD }_{t}\end{array}$ & $\begin{array}{c}-1.2608 \\
-0.6094 \\
-4.6341 \\
-7.2020 * \\
0.8323\end{array}$ & $\begin{array}{c}-2.4425 \\
-1.9145 \\
-6.8238 \\
-11.3779 \\
-17.7274\end{array}$ & $\begin{array}{l}-12.5620^{* *} \\
-14.5665^{* * *} \\
-20.4557^{* * *} \\
-45.0326^{* * *} \\
-11.8746^{* *}\end{array}$ & $\begin{array}{c}-24.4078^{* * *} \\
-21.1880^{* *} \\
-20.9461^{* *} \\
-40.2168^{* * *} \\
-17.2171^{*}\end{array}$ \\
\hline
\end{tabular}

Note: ${ }^{*} * *$ and ${ }^{* * *}$ show stationarity at $10 \%, 5 \%$ and $1 \%$ significant level.

Table A6. Bound testing.

\begin{tabular}{|c|c|c|c|c|c|}
\hline Country & f-Stat. & Hetero. & Serial Correlation & Normality & Functional Form \\
\hline \multicolumn{6}{|c|}{ Model: $\mathrm{LOC}_{\mathrm{t}}=\mathrm{f}\left(\mathrm{LGDPC}_{\mathrm{t}}, \mathrm{LGDPC}_{\mathrm{t}}{ }^{2}, \mathrm{LURB}_{\mathrm{t}}, \mathrm{LFMD}_{\mathrm{t}}\right)$} \\
\hline Iran & 3.0992 & $\begin{array}{c}1.0187 \\
(0.4203)\end{array}$ & $\begin{array}{c}0.5175 \\
(0.6346)\end{array}$ & $\begin{array}{c}0.7579 \\
(0.6863)\end{array}$ & $\begin{array}{c}0.0102 \\
(0.9199)\end{array}$ \\
\hline Iraq & 5.4353 & $\begin{array}{l}1.6349 \\
(0.1984)\end{array}$ & $\begin{array}{l}1.4528 \\
(0.2364)\end{array}$ & $\begin{array}{l}1.4606 \\
(0.4818)\end{array}$ & $\begin{array}{c}0.1498 \\
(0.7011)\end{array}$ \\
\hline Israel & 4.0520 & $\begin{array}{l}1.0993 \\
(0.3878)\end{array}$ & $\begin{array}{c}2.0145 \\
(0.1587)\end{array}$ & $\begin{array}{c}2.3813 \\
(0.3125)\end{array}$ & $\begin{array}{c}0.6698 \\
(0.4192)\end{array}$ \\
\hline Kuwait & 3.6041 & $\begin{array}{c}0.0519 \\
(0.8209)\end{array}$ & $\begin{array}{c}1.0884 \\
(0.3485)\end{array}$ & $\begin{array}{c}2.8246 \\
(0.2716)\end{array}$ & $\begin{array}{c}2.1770 \\
(0.1493)\end{array}$ \\
\hline Oman & 2.0058 & $\begin{array}{l}1.8020 \\
(0.1358)\end{array}$ & $\begin{array}{c}0.1446 \\
(0.8659)\end{array}$ & $\begin{array}{l}1.2864 \\
(0.5256)\end{array}$ & $\begin{array}{c}0.0345 \\
(0.8536)\end{array}$ \\
\hline Qatar & 4.2681 & $\begin{array}{c}0.9530 \\
(0.4947)\end{array}$ & $\begin{array}{l}1.9370 \\
(0.1612)\end{array}$ & $\begin{array}{c}0.0722 \\
(0.9646)\end{array}$ & $\begin{array}{l}2.0500 \\
(0.1619)\end{array}$ \\
\hline $\begin{array}{l}\text { Saudi } \\
\text { Arabia }\end{array}$ & 3.2552 & $\begin{array}{c}0.7819 \\
(0.5691)\end{array}$ & $\begin{array}{c}0.0281 \\
(0.9723)\end{array}$ & $\begin{array}{c}0.6998 \\
(0.6951)\end{array}$ & $\begin{array}{c}0.7251 \\
(0.3999)\end{array}$ \\
\hline UAE & 7.0495 & $\begin{array}{c}0.2487 \\
(0.6207) \\
\end{array}$ & $\begin{array}{c}0.0776 \\
(0.7824) \\
\end{array}$ & $\begin{array}{c}0.8167 \\
(0.6784) \\
\end{array}$ & $\begin{array}{c}0.8351 \\
(0.3674) \\
\end{array}$ \\
\hline \multicolumn{6}{|c|}{ Model: $\mathrm{LNGC}_{\mathrm{t}}=\mathrm{f}\left(\mathrm{LGDPC}_{\mathrm{t}}, \mathrm{LGDPC}_{\mathrm{t}}{ }^{2}, \mathrm{LURB}_{\mathrm{t}}, \mathrm{LFMD}_{\mathrm{t}}\right)$} \\
\hline Iran & 3.4919 & $\begin{array}{c}0.3892 \\
(0.5362)\end{array}$ & $\begin{array}{c}0.1829 \\
(0.8336)\end{array}$ & $\begin{array}{c}1.7220 \\
(0.4351)\end{array}$ & $\begin{array}{c}0.0324 \\
(0.8786)\end{array}$ \\
\hline Iraq & 3.4601 & $\begin{array}{c}0.5494 \\
(0.8110)\end{array}$ & $\begin{array}{l}1.5094 \\
(0.2286)\end{array}$ & $\begin{array}{l}0.5092 \\
(0.7752)\end{array}$ & $\begin{array}{l}2.2667 \\
(0.1339)\end{array}$ \\
\hline Israel & 5.7789 & $\begin{array}{l}1.6165 \\
(0.1466)\end{array}$ & $\begin{array}{l}1.2137 \\
(0.3117)\end{array}$ & $\begin{array}{c}0.2811 \\
(0.8461)\end{array}$ & $\begin{array}{c}1.7321 \\
(0.1832)\end{array}$ \\
\hline Kuwait & 9.0672 & $\begin{array}{l}1.7209 \\
(0.1922)\end{array}$ & $\begin{array}{l}1.4630 \\
(0.2462)\end{array}$ & $\begin{array}{c}0.6324 \\
(0.7289)\end{array}$ & $\begin{array}{l}2.1133 \\
(0.1802)\end{array}$ \\
\hline Oman & 3.9526 & $\begin{array}{c}1.9624 \\
(0.1178)\end{array}$ & $\begin{array}{c}1.9857 \\
(0.1613)\end{array}$ & $\begin{array}{c}2.9521 \\
(0.2345)\end{array}$ & $\begin{array}{c}1.4711 \\
(0.2451)\end{array}$ \\
\hline Qatar & 2.1947 & $\begin{array}{l}1.1498 \\
(0.3135)\end{array}$ & $\begin{array}{c}1.1882 \\
(0.3168)\end{array}$ & $\begin{array}{c}2.0631 \\
(0.3512)\end{array}$ & $\begin{array}{c}2.3292 \\
(0.1357)\end{array}$ \\
\hline $\begin{array}{l}\text { Saudi } \\
\text { Arabia }\end{array}$ & 8.1763 & $\begin{array}{l}1.3847 \\
(0.2658)\end{array}$ & $\begin{array}{l}2.4616 \\
(0.1045)\end{array}$ & $\begin{array}{l}1.8127 \\
(0.3931)\end{array}$ & $\begin{array}{l}0.1819 \\
(0.6774)\end{array}$ \\
\hline UAE & 4.9593 & $\begin{array}{c}0.9099 \\
(0.5590)\end{array}$ & $\begin{array}{c}0.9982 \\
(0.3820)\end{array}$ & $\begin{array}{l}2.3999 \\
(0.3012)\end{array}$ & $\begin{array}{l}1.1004 \\
(0.2936)\end{array}$ \\
\hline \multicolumn{6}{|c|}{ Critical F-values } \\
\hline $\begin{array}{l}\text { At } 1 \% \\
\text { At } 5 \% \\
\text { At } 10 \%\end{array}$ & $\begin{array}{l}\text { Lower } \\
\text { bound } \\
3.6031 \\
2.7620 \\
2.3688\end{array}$ & $\begin{array}{l}\text { Upper } \\
\text { bound } \\
4.5632 \\
3.6167 \\
3.1663\end{array}$ & & & \\
\hline
\end{tabular}




\section{References}

1. Grossman, G.M.; Krueger, A.B. Environmental Impacts of the North American Free Trade Agreement; NBER, Working paper 3914; NBER: Cambridge, MA, USA, 1991.

2. Rahman, A.; Murad, S.M.W.; Ahmad, F.; Wang, X. Evaluating the EKC Hypothesis for the BCIM-EC Member Countries under the Belt and Road Initiative. Sustainability 2020, 12, 1478. [CrossRef]

3. Sulaiman, C.; Rahim, A.S.A. Can Clean Biomass Energy Use Lower $\mathrm{CO}_{2}$ Emissions in African Economies? Empirical Evidence from Dynamic Long-Run Panel Framework. Environ. Sci. Pollut. Res. 2020, 27, 37699-37708. [CrossRef] [PubMed]

4. Akadiri, S.S.; Alola, A.A.; Usman, O. Energy Mix Outlook and the EKC Hypothesis in BRICS Countries: A Perspective of Economic Freedom vs. Economic Growth. Environ. Sci. Pollut. Res. 2021, 28, 8922-8926. [CrossRef] [PubMed]

5. Choi, E.; Heshmati, A.; Cho, Y. An Empirical Study of the Relationships between $\mathrm{CO}_{2}$ Emissions, Economic Growth and Openness. IZA Discussion Paper No. 5304, 1-29, 2010. Available online: http:/ / ftp.iza.org/dp5304.pdf (accessed on 2 March 2021).

6. Franklin, R.S.; Ruth, M. Growing Up and Cleaning Up: The Environmental Kuznets Curve Redux. Appl. Geogr. 2012, 32, 29-39. [CrossRef]

7. Menz, T.; Kuhling, J. Population Aging and Environmental Quality in OECD Countries: Evidence from Sulfur Dioxide Emissions Data. Popul. Environ. 2011, 33, 55-79. [CrossRef]

8. Chang, D.S.; Yeh, L.T.; Chen, Y. The Effects of Economic Development, International Trade, Industrial Structure and Energy Demands on Sustainable Development. Sustain. Dev. 2014, 22, 377-390. [CrossRef]

9. Alola, A.A.; Donve, U.T. Environmental Implication of Coal and Oil Energy Utilization in Turkey: Is the EKC Hypothesis related to Energy? Manag. Environ. Qual. 2021, 32, 1477-7835. [CrossRef]

10. Suri, V.; Chapman, D. Economic Growth, Trade and Energy: Implications for the Environmental Kuznets Curve. Ecol. Econ. 1998, 25, 195-208. [CrossRef]

11. Luzzati, T.; Orsini, M. Investigating the Energy-Environmental Kuznets Curve. Energy 2009, 34, 291-300. [CrossRef]

12. Pablo-Romero, M.D.P.; De Jesus, J. Economic Growth and Energy Consumption: The Energy-Environmental Kuznets Curve for Latin America and the Caribbean. Renew. Sustain. Energy Rev. 2016, 60, 1343-1350. [CrossRef]

13. Aboagye, S. The Policy Implications of the Relationship between Energy Consumption, Energy Intensity and Economic Growth in Ghana. OPEC Energy Rev. 2017, 41, 344-363. [CrossRef]

14. Aruga, K. Investigating the Energy-Environmental Kuznets Curve Hypothesis for the Asia-Pacific Region. Sustainability 2019, 11, 2395. [CrossRef]

15. Hundie, S.K.; Daksa, M.D. Does Energy-Environmental Kuznets Curve Hold for Ethiopia? The Relationship between Energy Intensity and Economic Growth. J. Econ. Struct. 2019, 8, 1-21. [CrossRef]

16. Li, S.; Shi, J.; Wu, Q. Environmental Kuznets Curve: Empirical Relationship between Energy Consumption and Economic Growth in Upper-Middle-Income Regions of China. Int. J. Environ. Res. Public Health 2020, 17, 6971. [CrossRef]

17. BP. BP Statistical Review of World Energy 2021. Available online: https://www.bp.com/statisticalreview (accessed on 2 January 2021).

18. Salahuddin, M.; Gow, J. Economic Growth, Energy Consumption and $\mathrm{CO}_{2}$ Emissions in Gulf Cooperation Council Countries. Energy 2014, 73, 44-58. [CrossRef]

19. Omri, A.; Daly, S.; Rault, C.; Chaibi, A. Financial Development, Environmental Quality, Trade and Economic Growth: What Causes What in MENA Countries. Energy Econ. 2015, 48, 242-252. [CrossRef]

20. Tolba, M.K.; Saab, N.W. Arab Environment: Climate Change. Impact of Climate Change on Arab Countries. Arab Forum for Environment and Developments, 1-182, 2009. Available online: https://www.preventionweb.net/files/12741_FullEnglishReport1.pdf (accessed on 8 March 2021).

21. Salahuddin, M.; Gow, J.; Ozturk, I. Is the Long-Run Relationship between Economic Growth, Electricity Consumption, Carbon Dioxide Emissions and Financial Development in Gulf Cooperation Council Countries Robust? Renew. Sustain. Energy Rev. 2015, 51,317-326. [CrossRef]

22. Callen, T.; Cherif, R.; Hasanov, F.; Hegazy, A.; Khandelwal, P. Economic Diversification in the GCC: The Past, the Present, and the Future. IMF Staff Discussion Note 2014, SDN/14/12, 1-32. Available online: https://www.imf.org/external/pubs/ft/sdn/2014 / sdn1412.pdf (accessed on 11 March 2021).

23. Zaied, Y.B.; Cheikh, N.B.; Nguyen, P. Long-run analysis of Environmental Kuznets Curve in the Middle East and North Africa. Environ. Econ. 2017, 8, 72-79. [CrossRef]

24. Hassan, M.S.; Iqbal, M.; Arshed, N. Distribution-based Effects of Disaggregated GDP and Environmental Quality-A Case of Quantile on Quantile Estimates. Environ. Sci. Pollut. Res. 2021. [CrossRef]

25. Chen, P.-Y.; Chen, S.-T.; Hsu, C.-S.; Chen, C.-C. Modeling the Global Relationships among Economic Growth, Energy Consumption and $\mathrm{CO}_{2}$ Emissions. Renew. Sustain. Energy Rev. 2016, 65, 420-431. [CrossRef]

26. Maneejuk, N.; Ratchakom, S.; Maneejuk, P.; Yamaka, W. Does the Environmental Kuznets Curve Exist? An International Study. Sustainability 2020, 12, 9117. [CrossRef]

27. Jin, T.; Kim, J. Investigating the Environmental Kuznets Curve for Annex I Countries Using Heterogeneous Panel Data Analysis. Environ. Sci. Pollut. Res. 2020, 27, 10039-10054. [CrossRef] [PubMed]

28. Hassan, M.S.; Meo, M.S.; Karim, M.Z.A.; Arshed, N. Prospects of Environmental Kuznets Curve and Green Growth: The Role of Globalization in Developed and Developing Economies. Estud. Econ. Apl. 2020, 38, 1-18. [CrossRef] 
29. Bongers, A. The environmental Kuznets curve and the energy mix: A structural estimation. Energies 2020, 13, 2641. [CrossRef]

30. Bibi, F.; Jamil, M. Testing Environment Kuznets Curve (EKC) Hypothesis in Different Regions. Environ. Sci. Pollut. Res. 2021, 28, 13581-13594. [CrossRef]

31. Shahzad, U.; Radulescu, M.; Rahim, S.; Isik, C.; Yousaf, Z.; Ionescu, S.A. Do Environment-Related Policy Instruments and Technologies Facilitate Renewable Energy Generation? Exploring the Contextual Evidence from Developed Economies. Energies 2021, 14, 690 .

32. Wang, F.; Wang, C.; Chen, J.; Li, Z.; Li, L. Examining the Determinants of Energy-Related Carbon Emissions in Central Asia: Country-Level LMDI and EKC Analysis during Different Phases. Environ. Dev. Sustain. 2020, 22, 7743-7769. [CrossRef]

33. Saboori, B.; Sulaiman, J. $\mathrm{CO}_{2}$ Emissions, Energy Consumption and Economic Growth in Association of Southeast Asian Nations (ASEAN) Countries: A Cointegration Approach. Energy 2013, 55, 813-822. [CrossRef]

34. Xue, L.; Haseeb, M.; Mahmood, H.; Alkhateeb, T.T.Y.; Murshed, M. Renewable Energy Use and Ecological Footprints Mitigation: Evidence from Selected South Asian Economies. Sustainability 2021, 13, 1613. [CrossRef]

35. Pao, H.-T.; Tsai, C.-M. $\mathrm{CO}_{2}$ Emissions, Energy Consumption and Economic Growth in BRIC Countries. Energy Policy 2010, 38, 7850-7860. [CrossRef]

36. Rufael, Y.W.; Weldemeskel, E.M. Environmental Policy Stringency, Renewable Energy Consumption and $\mathrm{CO}_{2}$ Emissions: Panel Cointegration Analysis for BRIICTS Countries. Int. J. Green Energy 2020, 17, 568-582. [CrossRef]

37. Miranda, R.A.; Hausler, R.; Lopez, R.R.; Glaus, M.; Pasillas-Diaz, J.R. Testing the environmental Kuznets curve hypothesis in North America's Free Trade Agreement (NAFTA) countries. Energies 2020, 13, 3104. [CrossRef]

38. Mahmood, H.; Maalel, N.; Zarrad, O. Trade Openness and $\mathrm{CO}_{2}$ Emissions: Evidence from Tunisia. Sustainability 2019, $11,3295$. [CrossRef]

39. Hashmi, S.H.; Hongzhong, F.; Fareed, Z.; Bannya, R. Testing nonlinear nexus between service sector and $\mathrm{CO}_{2}$ emissions in Pakistan. Energies 2020, 13, 0526. [CrossRef]

40. Mahmood, H.; Alkhateeb, T.T.Y.; Al-Qahtani, M.M.Z.; Allam, Z.; Ahmad, N.; Furqan, M. Agriculture Development and CO 2 Emissions Nexus in Saudi Arabia. PLoS ONE 2019, 14, e0225865. [CrossRef]

41. Alsamara, M.; Mrabet, Z.; Saleh, A.S.; Anwar, S. The Environmental Kuznets Curve Relationship: A Case Study of the Gulf Cooperation Council Region. Environ. Sci. Pollut. Res. 2019, 25, 33183-33195. [CrossRef]

42. Ansari, M.A.; Ahmad, M.R.; Siddique, S.; Mansoor, K. An Environment Kuznets Curve for Ecological Footprint: Evidence from GCC Countries. Carbon Manag. 2020, 11, 355-368. [CrossRef]

43. Mahmood, H.; Alrasheed, A.S.; Furqan, M. Financial Market Development and Pollution Nexus in Saudi Arabia: Asymmetrical Analysis. Energies 2018, 11, 3462. [CrossRef]

44. Ozokcu, S.; Ozdemir, O. Economic Growth, Energy, and Environmental Kuznets Curve. Renew. Sustain. Energy Rev. 2017, 72, 639-647. [CrossRef]

45. Kilic, C.; Balan, F. Is There an Environmental Kuznets Inverted-U Shaped Curve? Panoeconomicus 2018, 65, 79-94. [CrossRef]

46. Zarzoso, I.M.; Motrancho, A.B. Pooled Mean Group Estimation of an Environmental Kuznets Curve for CO 2 . Econ. Lett. 2004, 82, 121-126. [CrossRef]

47. Lee, C.-C.; Chiu, Y.-B.; Sun, C.-H. Does One Size Fit All? A Reexamination of the Environmental Kuznets Curve using the Dynamic Panel Data Approach. Rev. Agric. Econ. 2009, 31, 751-778. [CrossRef]

48. Simionescu, M.; Păuna, C.B.; Niculescu, M.-D.V. The Relationship between Economic Growth and Pollution in Some New European Union Member States: A Dynamic Panel ARDL Approach. Energies 2021, 14, 2363. [CrossRef]

49. World Bank. World Dev. Indicators; The World Bank: Washington, DC, USA, 2021.

50. Im, K.S.; Pesaran, M.H.; Shin, Y. Testing for Unit Roots in Heterogeneous Panels. J. Econ. 2003, 115, 53-74. [CrossRef]

51. Levin, A.; Lin, C.-F.; Chu, C.-S.J. Unit root tests in panel data: Asymptotic and finite-sample properties. J. Econ. 2002, 108, 1-24. [CrossRef]

52. Maddala, G.S.; Wu, S. A comparative study of unit root tests with panel data and a new simple test. Oxf. Bull. Econ. Stat. 1999, 61, 631-652. [CrossRef]

53. Kao, C. Spurious regression and residual-based tests for cointegration in panel data. J. Econ. 1999, 90, 1-44. [CrossRef]

54. Johansen, S. Statistical analysis of Cointegration Vectors. J. Econ. Dyn. Control. 1988, 12, 231-254. [CrossRef]

55. Pedroni, P. Panel cointegration: Asymptotic and finite sample properties of pooled time series tests with an application to the PPP hypothesis. Econ. Theory 2004, 20, 579-625. [CrossRef]

56. Westerlund, J. Testing for error correction in panel data. Oxf. Bull. Econ. Stat. 2007, 69, 709-748. [CrossRef]

57. Banerjee, A.; Dolado, J.J.; Mestre, R. Error-correction mechanism tests for cointegration in a single-equation framework. J. Time Ser. Anal. 1998, 19, 267-283. [CrossRef]

58. Pesaran, M.H.; Shin, Y.; Smith, R. Pooled mean group estimator of dynamic heterogeneous panels. J. Am. Stat. Assoc. 1999, 94, 621-634. [CrossRef]

59. Pedroni, P. Fully modified OLS for heterogeneous cointegrated panels. Adv. Econ. 2000, 15, 93-130.

60. Kao, C.; Chiang, M.H. On the estimation and inference of a cointegrated regression in panel data. Adv. Econ. 2000, 15, 179-222.

61. Ng, S.; Perron, P. Lag Length Selection and the Construction of Unit Root Tests with Good Size and Power. Econometrica 2001, 69, 1519-1554. [CrossRef] 
62. Pesaran, M.H.; Shin, Y.; Smith, R.J. Structural analysis of vector error correction models with exogenous I(1) variables. J. Econ. 2001, 97, 293-343. [CrossRef]

63. Kripfganz, S.; Schneider, D.C. Response Surface Regressions for Critical Value Bounds and Approximate p-Values in Equilibrium Correction Models; Economics Department Discussion Papers Series, Paper Number 19/01; University of Exeter: Exeter, UK, 2019. Available online: http:/ / people.exeter.ac.uk/RePEc/dpapers/DP1901.pdf (accessed on 12 January 2021). 